\title{
Foraminiferal biofacies and palaeoenvironmental evolution of an Oligo-Miocene cool-water carbonate succession in the Otway Basin, southeast Australia
}

\author{
STEPHEN J. GALLAGHER, KARINA JONASSON \& GUY HOLDGATE \\ School of Earth Sciences, The University of Melbourne, Parkville, Victoria 3052, Australia. email: s.gallagher earthsci.unimelb.edu.au
}

\begin{abstract}
This multidisciplinary study integrates facies studies and foraminiferal analyses to assess the palaeoenvironmental evolution of an Oligocene to Miocene cool-water carbonate succession in the Otway Basin, southeastern Australia. The cool-water carbonate succession in the Otway Basin records signals relating to the evolution of the Southern Ocean throughout the Cenozoic. The strata are correlated with the relative coastal onlap curve of Haq et al. (1988) and several sequences can be identified in three formations. The Early Oligocene Narrawaturk Formation ( $T A 4.5$ ) comprises near the base high-energy, inner shelf biofacies (lowstand systems tracts) and up-section to lower energy mid- to outer shelf marls (TST and maximum flooding surfaces) with storm events and/or minor shallowing intervals. Foraminiferal reworking and post-depositional dolomitization occurs at the top of this unit. The Late Oligocene Clifton Formation ( $T B 1.1$ and $T B$ 1.2.) was deposited in a relatively high-energy inner to mid-shelf environment. The base of this unit preserves evidence of a shift in biofacies that correlates to a major sea-level fall at the $\mathrm{Mid} /$ Late Oligocene boundary coincident with a major ice advance in Antarctica, and correlates with other Mid-Oligocene unconformities world-wide. The Late Oligocene Gellibrand Marl Formation (TB 1.2 and $T B$ 1.3) began with low-energy outer shelf cherty marly biofacies (TST and MFS) followed by mid- to outer shelf calcisiltites (HST). High-energy mid- to outer shelf conditions were established after an hiatus in the Late Oligocene. A relative sea-level rise at the base of the Lower Miocene (TB 1.5 and $T B 2.1$ ) led to the deposition of lower energy outer shelf cherty marls.

Four biofacies with distinctive foraminiferal faunas are distinguished. (1) Grey mid- to outer shelf lowenergy bryozoal marls with infaunal foraminifera and high plankton values. Two foraminiferal assemblages occur: lagenids and Uvigerina are common in the Narrawaturk marls, whereas bolivinids and Astrononion occur in the Gellibrand marls. The faunal variation in the marls may relate to changes in nutrient supply, anoxia, the presence or absence of organic material and/or changes in depth. (2) Chalky packstone facies with a high epifaunal content were deposited in oligotrophic inner to mid-shelf palaeoenvironments subject to intermittent reworking. (3) Bryozoan-poor inner to outer shelf foraminiferal packstones and grainstones facies enriched in epifaunal forms. (4) Well-sorted coarsegrained regular echinoid and bryozoan-rich packstones to grainstones. Infaunal taxa are absent in this facies, where most preserved foraminifera are robust spherical to discoidal forms. The facies were deposited in inner to mid-shelf palaeoenvironments where reworking by intense wave action (either above normal wavebase or by storms) winnowed out all smaller foraminifera.

The stratigraphic and palaeoenvironmental utility of the Cenozoic foraminifera studied is improved greatly by facies analyses. Similar integrated studies will lead to better correlations and palaeoenvironmental interpretations of southeastern Australian sequences and equivalent successions in the southern hemisphere. J. Micropalaeontol. 18(2): 143-168, December 1999
\end{abstract}

\section{INTRODUCTION}

The Otway Basin in southeast Australia extends over $400 \mathrm{~km}$ and occupies an area of around $60000 \mathrm{~km}^{2}$ (Fig. 1). It preserves a thick sequence of Mesozoic to Cenozoic sedimentary and volcanic rocks. It is one of a series of basins developed along the southern seaboard of the Australian continent that have a common basin-filling history, and was initiated by events leading up to and following the Gondwana continental rifting, break-up and northwards drifting of the Australian continent from Antarctica. A common theme through all of these basins is the transition from essentially non-marine Early Cretaceous sediments to more marine Tertiary conditions. This is thought to reflect the progressive opening of the Southern Ocean from Late Cretaceous times. By the late Eocene most of these basins had become predominantly marine and Australia lay around $30^{\circ}$ to $50^{\circ}$ South of the equator (Fig. 1). Thick sequences of cool-water carbonates (carbonates accumulating in sea water colder than $20^{\circ} \mathrm{C}$ ) were deposited in the temperate waters along Australia's southern margin during this time (James, 1997).
The Otway Basin is delimited to the north (onshore) by outcropping Palaeozoic basement rocks and to the south (offshore) by the toe of the present continental slope (Fig. 1). Mixed cool-water carbonate and clastic sediments are preserved in the Late Eocene to Early Oligocene Nirranda Group (Fig. 2). Open marine carbonates of the Heytesbury Group then prevailed during the Miocene. The exception is a thin interval in the early Late Oligocene when the mixed clastics and carbonate that constitutes the Clifton Formation were deposited (Fig. 2).

In the offshore part of the basin, Tertiary clastic and carbonate sediments have a progradational geometry on offshore seismic lines and downlap onto a latest Cretaceous unconformity. Progressively thicker and younger carbonate wedges extend the modern day shelf southwards into the Southern Ocean.

The foraminiferal biofacies, palaeoenvironmental and sequence stratigraphic evolution of the Oligocene to Miocene Nirranda Group and Heytesbury Group clastic and carbonate 


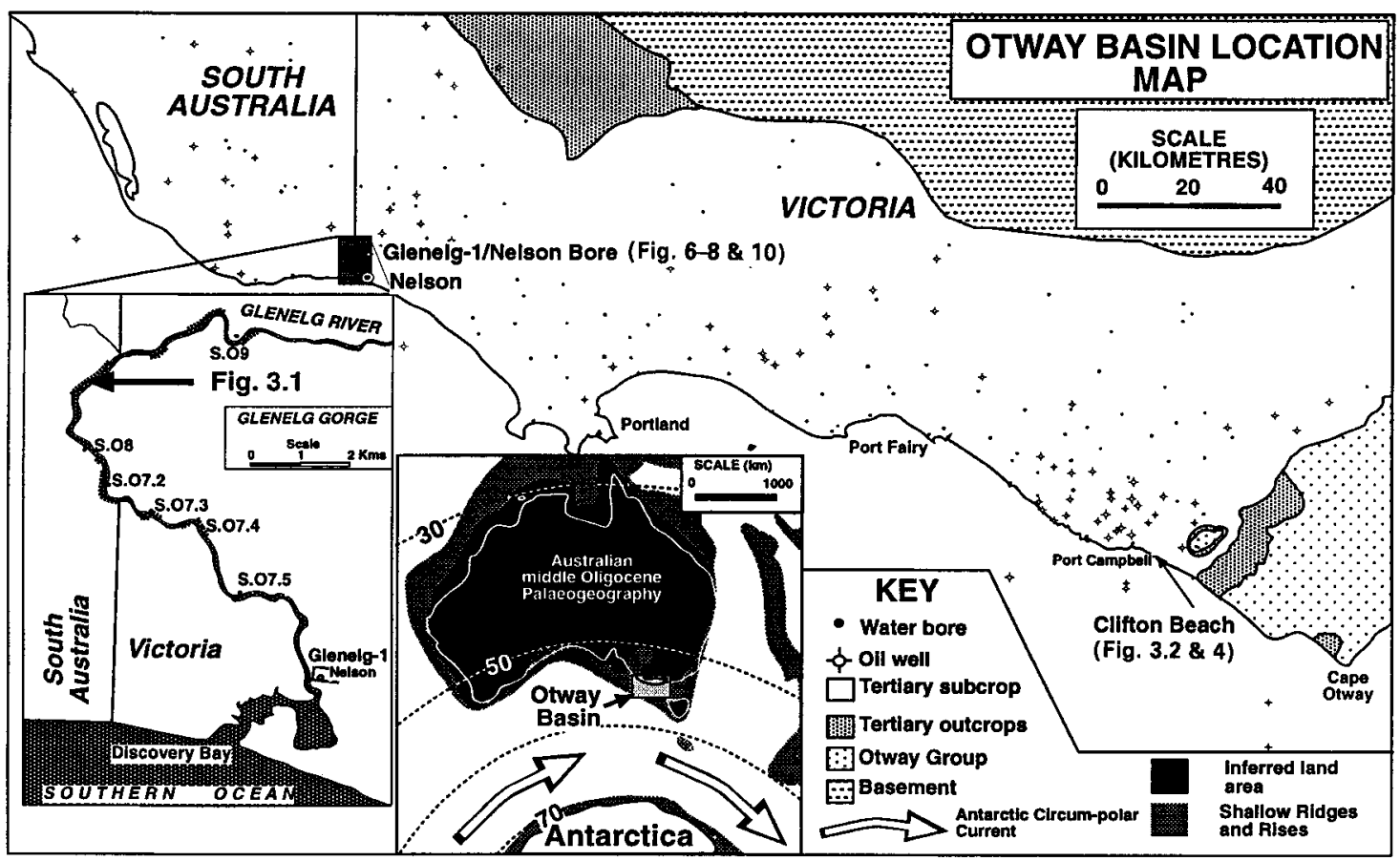

Fig. 1. Map of the Otway Basin showing the distribution of all wells and bores with Tertiary strata. The localities sampled in this study are indicated. The middle Oligocene ( $30 \mathrm{Ma}$ ) palaeogeography of Southern Ocean is adapted from Veevers et al. (1991). The paleoceanographic features of the Southern Ocean are adapted from Kennett (1977) and Kennett \& von der Borch (1986).

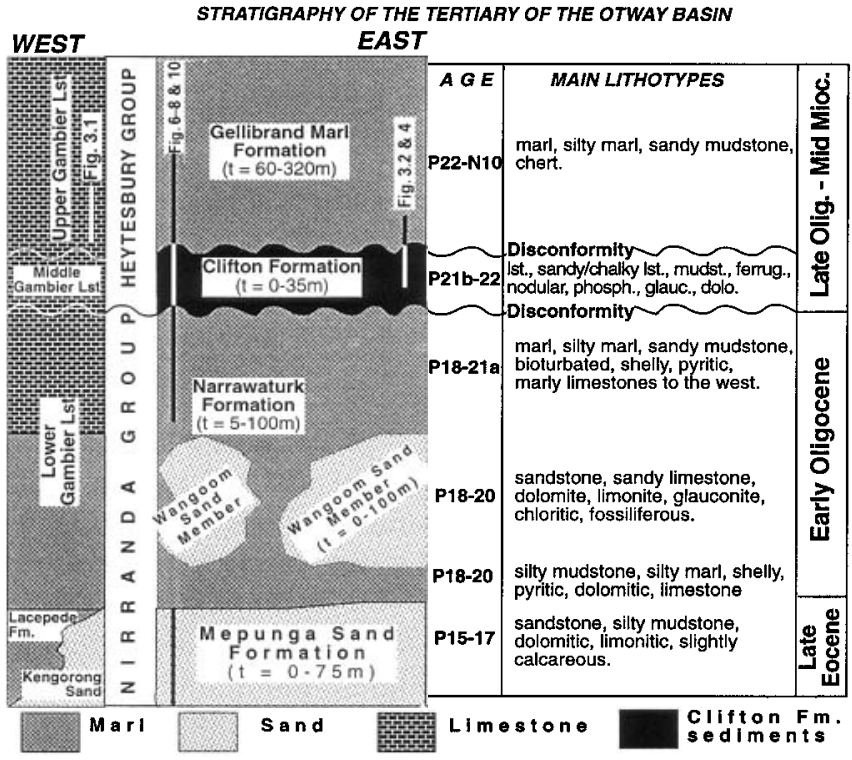

Fig. 2. Eocene to Miocene stratigraphy of the Otway Basin (not to scale). The approximate stratigraphic position of the sections exposed at Glenelg Gorge (Fig. 3.1), the Glenelg-1 bore (Figs 68 and 10) and the Clifton Formation outcrop at Port Campbell (Fig. 3.2 and 4) are shown. Note also the absence of the Wangoom Sand Member and the older parts of the Narrawaturk Marl in Glenelg-1 bore. sediments are the focus of this paper. They record the Palaeogene to Neogene history of events surrounding the progressive opening of the Southern Ocean.

The purposes of the combined facies and foraminiferal analyses were:

(1) to document the biostratigraphy;

(2) to gain an understanding of the biofacies evolution of the Narrawaturk, Clifton and Gellibrand Marl Formations;

(3) to determine the palaeoenvironmental evolution of the strata;

(4) to correlate the strata with global sea-level curves; and

(5) to determine the biofacies distribution of the foraminiferal faunas.

The principal biostratigraphically and palaeoenvironmentally significant foraminiferal taxa documented are illustrated in Plates 1 and 2.

\section{METHODS}

The samples for the analyses were obtained from the Glenelg-1 bore at Nelson (Fig. 1). The Glenelg-1 bore was continuously cored in 1941 (Crespin, 1954) and representative samples were retained every $2-3 \mathrm{~m}$. Thirty-six samples of core were processed for foraminifera from this bore. Twenty-nine of these 36 samples were studied and used for quantitative foraminiferal analyses; the remainder were qualitative samples for biostratigraphic purposes. Nearly 300 foraminifera were picked, sorted and identified from each sample for the quantitative analyses. A total of 170 benthonic and 35 species of planktonic foraminifera were identified in over 7000 foraminifera studied from the Glenelg-1 




Explanation of Plate 1

Illustration of key biostratigraphically important taxa from the Oligo-Miocene of the Otway Basin. Horizontal bar $=0.1 \mathrm{~mm}$. fig. 1. Subbotina angiporoides (Hornibrook), Glenelg-1, $807 \mathrm{ft}(246 \mathrm{~m})$. fig. 2. Chiloguembelina cubensis (Palmer), Glenelg-1, $807 \mathrm{ft}(246 \mathrm{~m})$. fig. 3. Globoturborotalia labiacrassata (Jenkins), Glenelg-1, $807 \mathrm{ft}(246 \mathrm{~m})$. fig. 4. Paragloborotalia nana (Bolli), Glenelg-1, $807 \mathrm{ft}(246 \mathrm{~m})$. fig. 5. Bolivinopsis cubensis (Cushman \& Bermudez), Glenelg-1, $807 \mathrm{ft}(246 \mathrm{~m})$. fig. 6. Globoturborotalia angulisuturalis (Bolli), Glenelg-1, $494 \mathrm{ft}(150.6 \mathrm{~m})$. figs 7,8 . Tenuitellinata angustiumbilicata (Bolli), Glenelg-1, 494 \& $453 \mathrm{ft}$. fig. 9. Globoturborotalia euapertura (Jenkins), Glenelg-1, $494 \mathrm{ft}(150.6 \mathrm{~m})$. figs 10, 11. Globorotalia kugleri sensu lato Bolli, Glenelg-1, $494 \mathrm{ft}(150.6 \mathrm{~m})$. fig. 12. Globoturborotalia woodi (Jenkins), Glenelg-1, $310 \mathrm{ft}(94.5 \mathrm{~m})$.

bore (see Appendices A and B for faunal lists and percentage values). A further four samples are from the Clifton Formation type section near Port Campbell (Fig. 1) and are encorporated in this study to help correlate this Middle Oligocene interval from outcrop into the subsurface. At this locality, over 108 benthic and 10 planktonic species were identified in the 1000 foraminifera collected (see Appendix $\mathrm{C}$ for full faunal list). The data collected are illustrated as percentages of the total, benthic or planktonic faunas in Figures 6-9. In addition to these sections, nine samples were processed and biostratigraphic data obtained from the base of several cliff sections at river level in Glenelg Gorge (Figs 1 and 3.1).

The facies analyses used to construct the logs in Figs 4 and 6 were carried out principally by two methods: logging the core by texture, using a hand lens in a core store and analysing the unprocessed microfossil samples; and using a binocular microscope in the laboratory. Facies were classified using the Folk Classification, grain size (calcilutite, calcarenite, marl), and bioclast type and preservation. The key to Fig. 4 is given in Fig. 5.

\section{LITHOSTRATIGRAPHY}

The stratigraphic setting of the three formations sampled for foraminifera is indicated in Fig. 2. Strata of the Narrawaturk Marl, Clifton and Gellibrand Marl formations in the South Australian part of the western Otway Basin have variously been referred to whole or part of the Gambier Limestone (McGowran, 1973; Moss \& McGowran, 1993), with equivalents to the Mepunga Formation referred to the Kongorong Sand (Ludbrook, 1971).

Recognition of the Clifton Formation (the Middle Gambier Limestone) in the South Australian sector of the Otway Basin is based on electric log correlations and biostratigraphy. Because the underlying and overlying carbonates are more carbonaterich in this area, the characteristic Victorian lithological features of the Clifton Formation are less well expressed. However, sufficient subsurface data now provide good control to carry the Victorian nomenclature into South Australia. Therefore, the Middle Gambier Limestone of McGowran (1973) is largely equivalent to the Clifton Formation, and the Upper Gambier Limestone is equivalent to the Oligocene part of the Gellibrand 


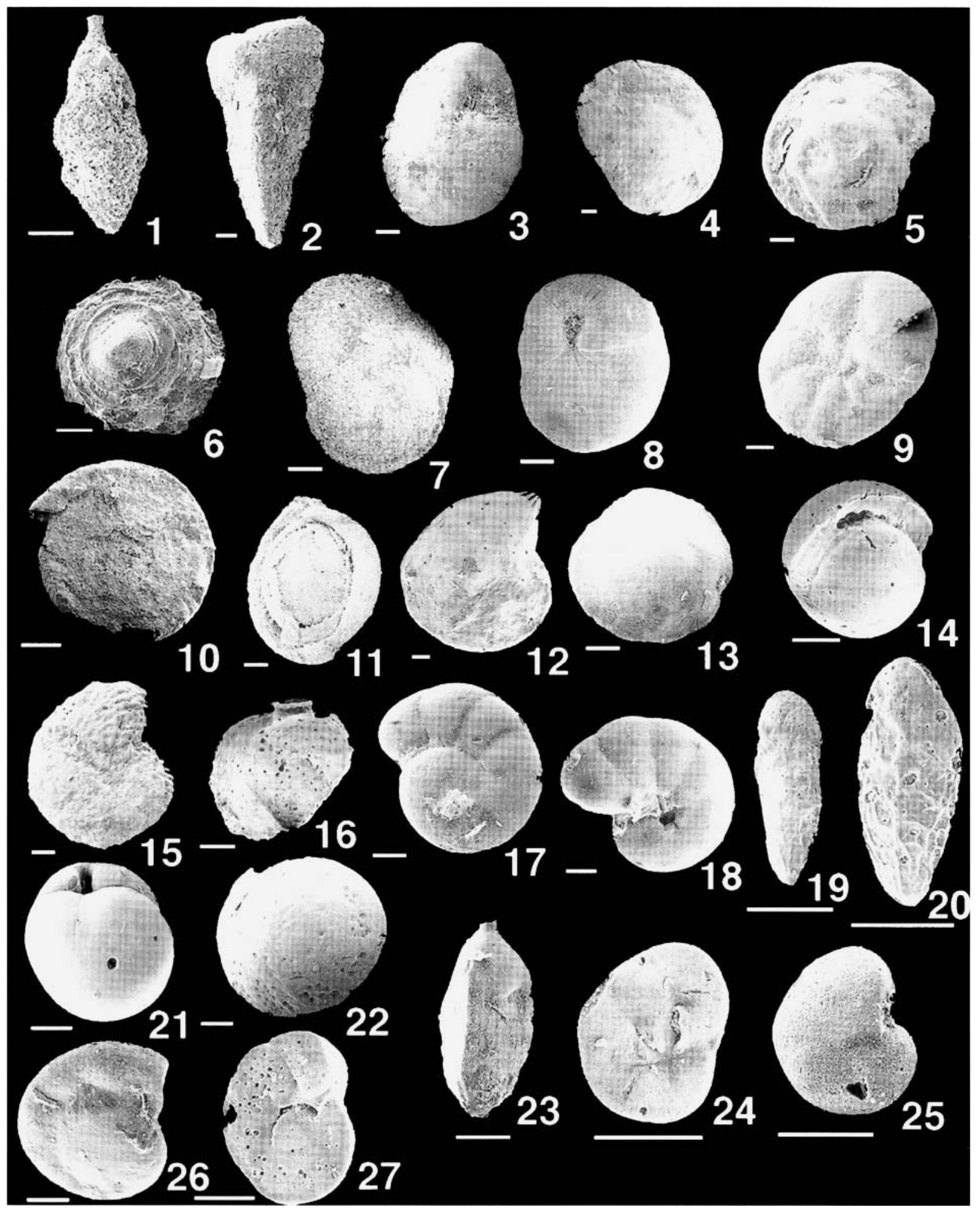

Explanation of Plate 2.

Illustration of key palaeoenvironmentally important taxa from the Oligo-Miocene of the Otway Basin, the taxa are arranged in the same order as their abundance peaks in figs 7 and 8 . Horizontal bar $=0.1 \mathrm{~mm}$ : fig. 1. Uvigerina proboscidea Schwager, Glenelg-1, $689 \mathrm{ft}(210 \mathrm{~m})$. fig. 2. Gaudryina crespinae Cushman, Glenelg- $1,689 \mathrm{ft}(210 \mathrm{~m})$. figs 3, 4. Eponides lornensis Finlay, Glenelg-1, $689 \mathrm{ft}(210 \mathrm{~m})$. figs 5, 9. Stomatorbina concentrica (Parker \& Jones), Glenelg-1, $689 \mathrm{ft}(210 \mathrm{~m})$. fig. 6. Patellina corrugata Williamson, Glenelg-1, $689 \mathrm{ft}(210 \mathrm{~m})$. figs 7, 8. Heronallenia parri Carter, Glenelg-1, $646 \mathrm{ft}(197 \mathrm{~m})$. fig. 10. Spirillina involvens (Reuss), Glenelg-1, $625 \mathrm{ft}(190 \mathrm{~m})$. fig. 11. Mould of Quinqueloculina sp., Glenelg-1, $578 \mathrm{ft}(176 \mathrm{~m})$. fig. 12. Lenticulina sp., Glenelg-1, $465 \mathrm{ft}$. fig. 13. Heterolepa brevoralis (Carter), Glenelg-1, $465 \mathrm{ft}(142 \mathrm{~m})$. fig. 14. Pullenia bulloides (d'Orbigny), Glenelg-1, $494 \mathrm{ft}(150.6 \mathrm{~m})$. fig. 15. Parrellina crespinae (Cushman), Glenelg-1, $517 \mathrm{ft}(157.6 \mathrm{~m})$. fig. 16. Siphonina australis Cushman, Glenelg-1, $494 \mathrm{ft}(150.6 \mathrm{~m})$. figs 17, 18. Anomalinoides macroglabra (Finlay), Glenelg-1, $465 \& 720 \mathrm{ft}(219 \mathrm{~m}$ ). fig. 19. Bolivina lapsus Finlay, Glenelg-1, $132 \mathrm{ft}(40 \mathrm{~m})$. fig. 20. Bolivina cf. pontis Finlay, Glenelg-1, $132 \mathrm{ft}(40 \mathrm{~m})$. fig. 21. Globocassidulina subglobosa (Brady), Glenelg-1, $812 \mathrm{ft}(247 \mathrm{~m})$. fig. 22. Cibicidoides perforatus (Karrer), Glenelg-1, $812 \mathrm{ft}(247 \mathrm{~m})$. fig. 23. Trifarina bradyi Cushman, Glenelg-1, $807 \mathrm{ft}(246 \mathrm{~m})$. figs 24,25 . Discorbinella berthloti (d’Orbigny), Glenelg-1, $132 \mathrm{ft}(40 \mathrm{~m})$. fig. 26. Gyroidinoides zelandicus (Finlay), Glenelg-1, $790 \mathrm{ft}(241 \mathrm{~m})$. fig. 27. Cibicides mediocris Finlay, Glenelg-1, $172 \mathrm{ft}(52 \mathrm{~m})$. 

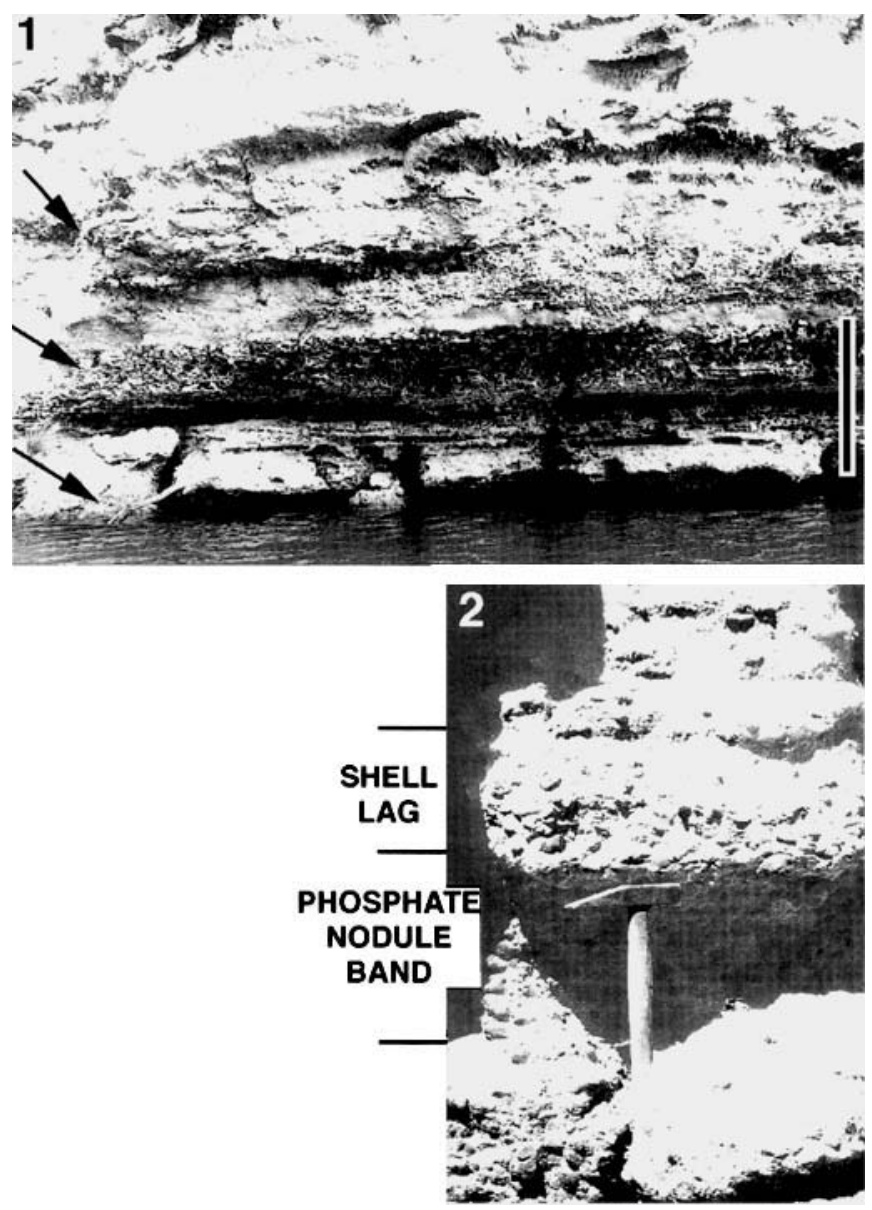

Fig. 3. (1) Gellibrand Marl Formation (Upper Gambier Limestones) with burrow chert bands (arrowed) exposed along the Glenelg River in Glenelg Gorge (Fig. 1). Vertical scale $1 \mathrm{~m}$. (2) Phosphate nodule band at Clifton Beach (Fig. 1) overlain by a shell lag (see Fig. 4 for log of the Clifton section). The exposed part of the hammer is $0.3 \mathrm{~m}$ long.

Marl (Fig. 2). Because of stratigraphic precedent, the Victorian nomenclature ideally takes priority over the more localized South Australian nomenclature and is used throughout this paper.

\section{AGE DETERMINATION}

Over 35 species of planktonic foraminifera were documented in the Glenelg-1 bore and Clifton Formation type section at Port Campbell. The distribution of key planktonic species and groups in the Clifton outcrop section and the Glenelg-1 bore are illustrated in Figs 4 and 6 (see also Appendices A3, B3 and C2). An illustration of important zonal taxa from these sections is shown in Plate 1. The eight samples from the Glenelg Gorge (Fig. 1) were picked only for planktonic foraminifera and the fauna is discussed in the following. The plankton datums used follow the biostratigraphic schemes outlined in Lindsay (1985), Holdgate \& Gallagher (1997) and McGowran et al. (1997). The plankton distribution is described in four parts: (1) the Narrawaturk Formation; (2) the Clifton Formation; (3) the Gellibrand Marl Formation; and (4) the Glenelg Gorge section.

\section{Narrawaturk Formation}

Planktonic foraminifera comprise $30-60 \%$ of the fauna of the Narrawaturk Formation in the Glenelg-1 bore (Fig. 6). Towards the top of the unit the plankton diversity declines markedly. Early Oligocene plankton are abundant in the Narrawaturk Formation and include tenuitinellids (Tenuitella juvenilis and $T$. gemma), Guembelitria triseriata, Chiloguembelina cubensis, Globoturborotalia labiacrassata, Paragloborotalia ampliaperiura and $P$. nana). The last appearance datum (LAD) of Subbotina angiporoides at $770 \mathrm{ft}(234.7 \mathrm{~m})$ provides an Early Oligocene (P20) age for the lower part of this unit. Another taxon present below this datum is Globigerina brevis. The LAD of $C$. cubensis at $597 \mathrm{ft}(182 \mathrm{~m})$ suggests an Early Oligocene (P21a) age for most of the Narrawaturk Formation. Additional LAD depths in this interval include that of $P$. ampliapertura and $P$. nana at $646 \mathrm{ft}$ $(197 \mathrm{~m})$. Above $597 \mathrm{ft}(182 \mathrm{~m})$ the plankton record in the Narrawaturk Formation is non-diagnostic and impoverished due to facies control (see later); however, the LAD of T. gemma at $578 \mathrm{ft}(176 \mathrm{~m})$ suggests an Early Oligocene age for this interval.

\section{Clifton Formation}

Plankton content ranges from 5-25\% in the Clifton Formation in outcrop and in the Glenelg-1 bore (Figs 4 and 6). The first appearance datum (FAD) of Paragloborotalia opima suggests a Late Oligocene age for the base of the Clifton Formation at $534 \mathrm{ft}(163 \mathrm{~m})$ in the Glenelg-1 bore. The first occurrence of the late Oligocene (P22) indicator species $T$. angulisuturalis, $T$. angustiumbilicata and $G$. ciperoensis at $494 \mathrm{ft}(150.6 \mathrm{~m})$ in the upper part of the Clifton Formation probably indicates that the strata below these datums have a P21b age. Other datums in the Clifton Formation of the Glenelg-1 bore include the FAD of Globigerina praebulloides and G. labiacrassata, and the LAD of the benthic agglutinated taxon Bolivinopsis cubensis.

The lowermost sample of the Clifton Formation in the type section near Port Campbell (Fig. 4) contains G. labiacrassata, with common $G$. ciperoensis and $G$. praebulloides. This assemblage is likely to be Late Oligocene in age. G. angustiumbilicata first occurs in the next sample up-section, followed by $G$. angulisuturalis and G. opima (Fig. 4). The data suggest that, other than the basal sample, which is probably a P21b, the upper units in the type section of the Clifton Formation belongs to $\mathrm{P} 22$.

\section{Gellibrand Marl Formation}

Planktonic foraminifera are common in the Gellibrand Marl Formation in the Glenelg-1 bore (Fig. 6), comprising between 10 and $40 \%$ of the total foraminiferal fauna. The most common taxa are $G$. praebulloides, $G$. ciperoensis and the tenuitinellids, $T$. juvenalis and T. munda. Globoturborotalia and Paragloborotalia also occur throughout this unit. The LAD of Globoturborotalia euapertura at $348 \mathrm{ft}(106 \mathrm{~m})$ in the absence of Globoquadrina dehiscens suggests a Late Oligocene N4a subzonal age for the lower part of the Gellibrand Marl Formation. Another important datum occurs at $410 \mathrm{ft}(125 \mathrm{~m})$, with the LAD of $G$. triseriata. The FAD of Globoturborotalia woodi at $310 \mathrm{ft}$ $(94.5 \mathrm{~m}$ ), followed by Globorotalia kugleri (sensu lato) at $293 \mathrm{ft}$, indicates an Early Miocene N4b subzonal age for the Gellibrand Marl Formation. The rest of the section in Glenelg- 1 is N5 based 


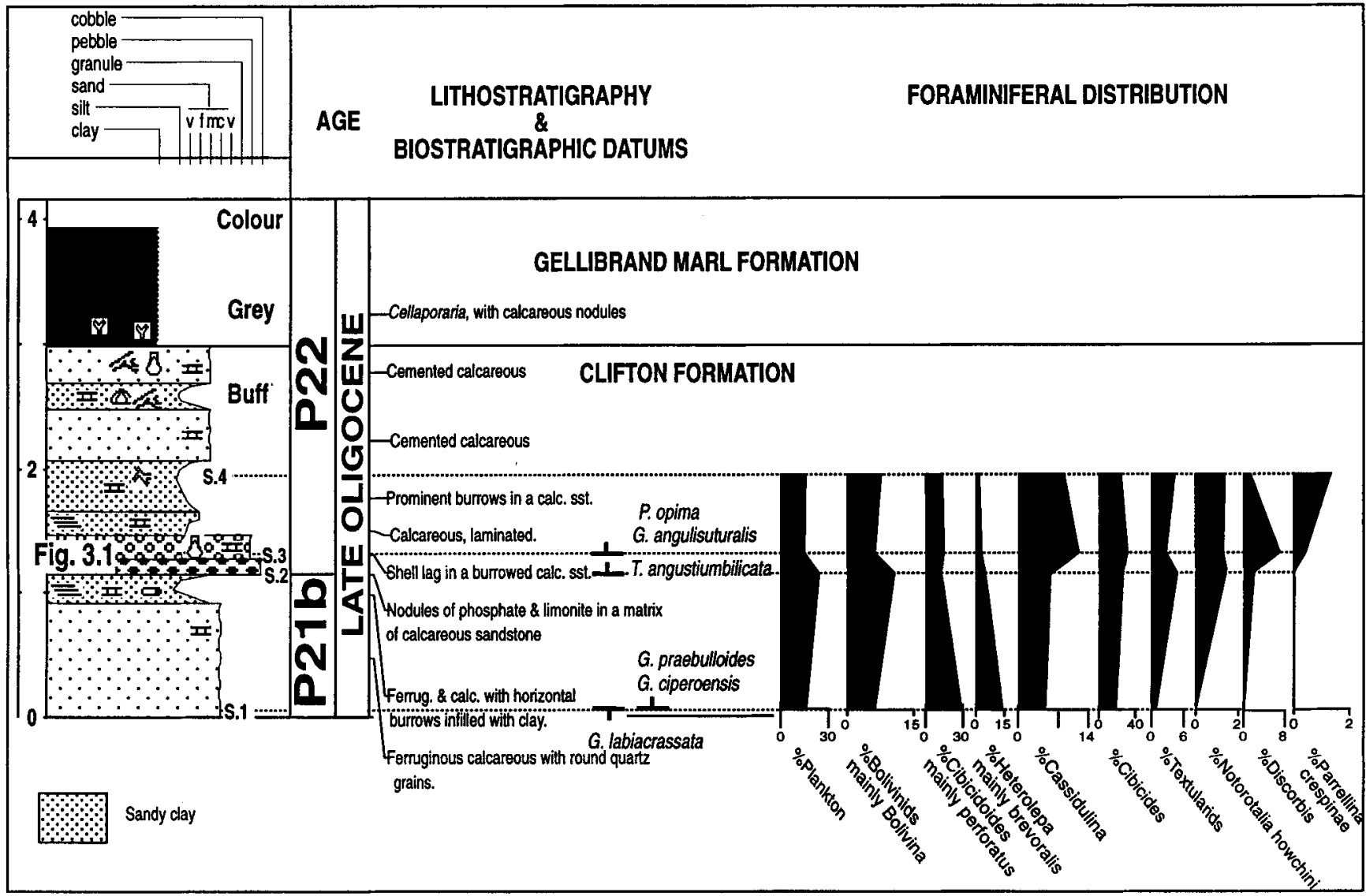

Fig. 4. Bio- and lithostratigraphy of the Clifton Formation type section outcrop at Clifton Beach (Fig. 1). The log height is in metres. The benthic foraminiferal distribution is expressed as a percentage of benthos. The plankton percentage is a proportion of the total fauna. See Appendix $\mathrm{C}$ for the faunal data.

on the FAD of Globoturborotalia connecta at $253 \mathrm{ft}(77 \mathrm{~m})$.

\section{Age of the strata in the Glenelg Gorge}

The nine samples contain a diverse planktonic foraminiferal assemblage. Samples 07.1, 07.2, 07.3 and 07.4 are from strata at river level and contain $G$. kugleri, $G$. angulisuturalis, $T$. angustiumbilicata, $G$. ciperoensis and $G$. euapertura, indicating a Late Oligocene P22 zonal age. Samples 07.5 and O8 contain $G$. woodi, but lack $G$. euapertura, and are Early Miocene (N4b) in age. Operculina victoriensis and Globigerinoides trilobus/bisphaerica occur in sample 0.9, suggesting an upper Early Miocene to lower Middle Miocene N6/N7 age for the most northerly limestones exposed along the Glenelg River. The limestones in Glenelg Gorge are equivalent to the Gellibrand Marl Formation/Upper Gambier Limestone (Fig. 2). The exposure of the limestones at river level in Glenelg Gorge is caused by large open folds.

\section{FACIES ANALYSIS}

This section describes the distribution of the foraminifera and facies in the Early Oligocene to Early Miocene of Glenelg-1 bore and the Clifton Formation type section, as illustrated on Figs 4, 7 and 8 (see Appendices A-C). This forms a framework for the palaeoenvironmental and sequence stratigraphic interpretations (see later). Plate 2 illustrates several significant benthonic foraminiferal taxa used in palaeoenvironmental analyses; these are figured in the same order as shown on Figs 7 and 8 . The order of foraminiferal taxa listed in Fig. 7 follows the peak abundance of each particular taxon from the base of Glenelg-1 bore to the top. The method used to calculate the standardized foraminiferal diversity is included in the caption of Fig. 8; the values used for this calculation can be found in Appendix A3. The foraminiferal data used to calculate the foraminiferal percentages are listed in Appendices A1-A3. The palaeoenvironmental interpretations are based on comparisons with extant forms (Fig. 9) with reference to Vella (1962), Hayward (1990), Murray (1991), Jones \& Yassini (1995) and Li et al. (1996a, 1996b).

\section{Narrawaturk Formation}

The Narrawaturk Formation in the Glenelg-1 bore can be divided into two distinctive lithofacies intervals (Fig. 7): Interval A $[812-640 \mathrm{ft}=247-195 \mathrm{~m}]$ consists of alternations of bryozoal marls, calcisiltites and chalk (with abundant foraminifera) and Interval B $(639-536 \mathrm{ft}=195-163 \mathrm{~m})$ consists of calcarenites and dolomite (with rare foraminifera). 


\begin{tabular}{|l|l|}
\hline LEGEND \\
LITHOLOGY \\
Sand/Sandstone
\end{tabular}

Fig. 5. Key to Figs 4 and 10.

Interval A: facies. The lowest sample $(812 \mathrm{ft}=247 \mathrm{~m})$ of Narrawaturk Formation in the Glenelg-1 bore consists of white, partially dolomitized glauconitic calcarenite and marl. Bioclasts include rounded, regular echinoid spines and stick bryozoa. Rounded limonite-stained quartz grains are common in this sample. Grey bryozoal marl (wackestone) alternates with white calcisiltite (packstone) above $812 \mathrm{ft}(247 \mathrm{~m})$. Bioclasts in the marls consist predominantly of stick bryozoans, rare sheet bryozoans, regular echinoid plates and brachiopods. Sponge spicules are abundant in some samples. The relative bioclast abundance in the calcisiltites varies: a cemented horizon at $780 \mathrm{ft}$ $(238 \mathrm{~m})$ contains few bioclasts, of bryozoans, molluses and irregular echinoid spines, whereas the sample at $720 \mathrm{ft}(219 \mathrm{~m})$ contains abundant stick bryozoa. Twenty feet $(6 \mathrm{~m})$ of stick bryozoan-rich, white, chalky calcisiltite (packstone) occurs towards the top of this interval.

Interval A: Foraminifera. Foraminifera are abundant and diverse in the lower Narrawaturk Formation in the Glenelg-1 bore (Figs 7 and 8). Samples commonly yield between 40 and 50 species of foraminifera, with standardized diversity values of around 20 . The number of taxa in each sample peaks between $646 \mathrm{ft}(197 \mathrm{~m})$ and $720 \mathrm{ft}(219 \mathrm{~m})$, corresponding to an up-section reduction in the percentage of Cibicidoides perforatus, infaunal taxa (see Appendix A for list of infaunal forms) and Globocassidulina subglobosa. The four major facies in Interval A have distinctive assemblages (Fig. 7).

(a) Dolomitized sand calcarenite. The sample at $812 \mathrm{ft}(247 \mathrm{~m})$ has a low-diversity, plankton-poor assemblage, predominantly of large specimens (>1 mm) of Globocassidulina subglobosa and Cibicidoides perforatus, with lesser Gyroidinoides allani.

(b) Bryozoan marls. Planktonic foraminifera, Cibicides and infaunal taxa, such as Fissurina and Astrononion, are common. Uvigerina proboscidea and Eponides lornensis are also present and increase upwards to peak in abundance at $689 \mathrm{ft}(210 \mathrm{~m})$. Textulariids, such as Gaudryina crespinae and Bolivinopsis cubensis, are more common in the marl than in the calcisiltite and peak at $12 \%$ (also at $689 \mathrm{ft}=210 \mathrm{~m}$ ) of the total benthic fauna. Victoriella conoidea first occurs up-section at $689 \mathrm{ft}$ $(210 \mathrm{~m})$.

(c) Calcisiltite and chalk. Stomatorbina concentrica and Patellina corrugata are most abundant in calcisiltite and chalk between $646 \mathrm{ft}(197 \mathrm{~m})$ and $746 \mathrm{ft}(227 \mathrm{~m})$. Spirillina and Heronallenia may occur in this facies.

Other important components of the assemblage showing no particular facies preference include minor peaks of Gyroidinoides, Trifarina, Lenticulina, Sphaeroidina bulloides and the bolivinids (Fig. 8).

Important faunal trends in this interval include:

(1) the highest plankton values are recorded in the lower most marl at $807 \mathrm{ft}(246 \mathrm{~m})$, corresponding to a high species diversity;

(2) the percentage of planktonics, percentage of infaunal foraminifera with Globocassidulina subglobosa and Cibicidoides perforatus all decrease upwards in abundance to $640 \mathrm{ft}(195 \mathrm{~m})$;

(3) the percentage of textulariids, such as Gaudryina crespinae, and of Uvigerina proboscidea and Eponides lornensis, increase upward to a maximum at $689 \mathrm{ft}$ $(210 \mathrm{~m})$ and then decrease in abundance;

(4) Stomatorbina concentrica, Heronallenia, Spirillina and Patellina are absent from the base of the Narrawaturk Formation. These taxa peak in the chalk at $646 \mathrm{ft}$ $(197 \mathrm{~m})$; and

(5) Trifarina and species diversity increase in abundance upwards to the chalk.

Interval A: palaeoenvironment and biofacies. The mixed carbonate/clastic content of the lowermost sample in the Narrawaturk Formation is interpreted as the initial transgressive facies of this unit, where reworking of the underlying Mepunga Sand Formation has occurred. The low diversity of plankton and relatively large benthonic assemblage ( $>1 \mathrm{~mm}$ tests) probably relates, in part, to the partial dolomitization of the sample, and to current reworking which may have winnowed out the smaller taxa.

The stick bryozoan-rich marl (wackestone) is inferred to have been deposited in low-energy shelf palaeoenvironments. The grey colour may reflect the presence of either clay and/or organic material. This low-energy facies is characterized by high plankton values, small-sized diverse assemblages and the presence of common infaunal taxa such as Uvigerina and Astrononion that prefer muddy substrates in modern environments (Murray, 1991). The calcisiltite (packstone) facies was 




Fig. 6. Facies, bio- and lithostratigraphy of the Glenelg-1 bore. The log depths are in feet ( $80-920 \mathrm{ft})$ and metres ( $50-250 \mathrm{~m})$. Note: the values for each planktonic taxon are expressed as a percentage of the total plankton; these percentage values were calculated to illustrate the distribution of all plankton taxa relative to each other. The diagonal hatch denotes an interval where the biozonation is thought to be tentative due to faunal recrystallization as a result of dolomitization. See Appendices A and B for the faunal data

deposited in higher energy shelf palaeoenvironments than the marl, although not very high, as no obvious bioclast sorting is seen. The presence of regular echinoid plates and spines in this facies is indicative of the relatively coarse nature of the substrate. The white colour and often chalky nature reflects a low clay and/or organic content, as these components would have been winnowed out. The relatively large grain size and lack of any organic content of this facies is associated with low abundances of plankton and infaunal taxa.

From the base to the top of this interval, the following palaeoenvironmentally significant events have occurred. The basal clastic-rich sample of the Narrawaturk Formation contains the mid- to outer shelf taxa G. subglobosa [this taxon may occur in inner shelf settings where upwelling occurs (Li et al., 1996)] and G. allani, and represents the initial high-energy transgressive facies. Transgressive facies often preserve the signals of cool upwelling palaeoenvironments (Holdgate \& Gallagher, 1997). If the low-diversity assemblage and $G$. subglobosa abundance at this level were caused by upwelling in this initial transgressive phase, the Narrawaturk Formation was probably deposited in a high-energy, inner shelf palaeoenvironment. Similar assemblages (with relatively less G. subglobosa) 


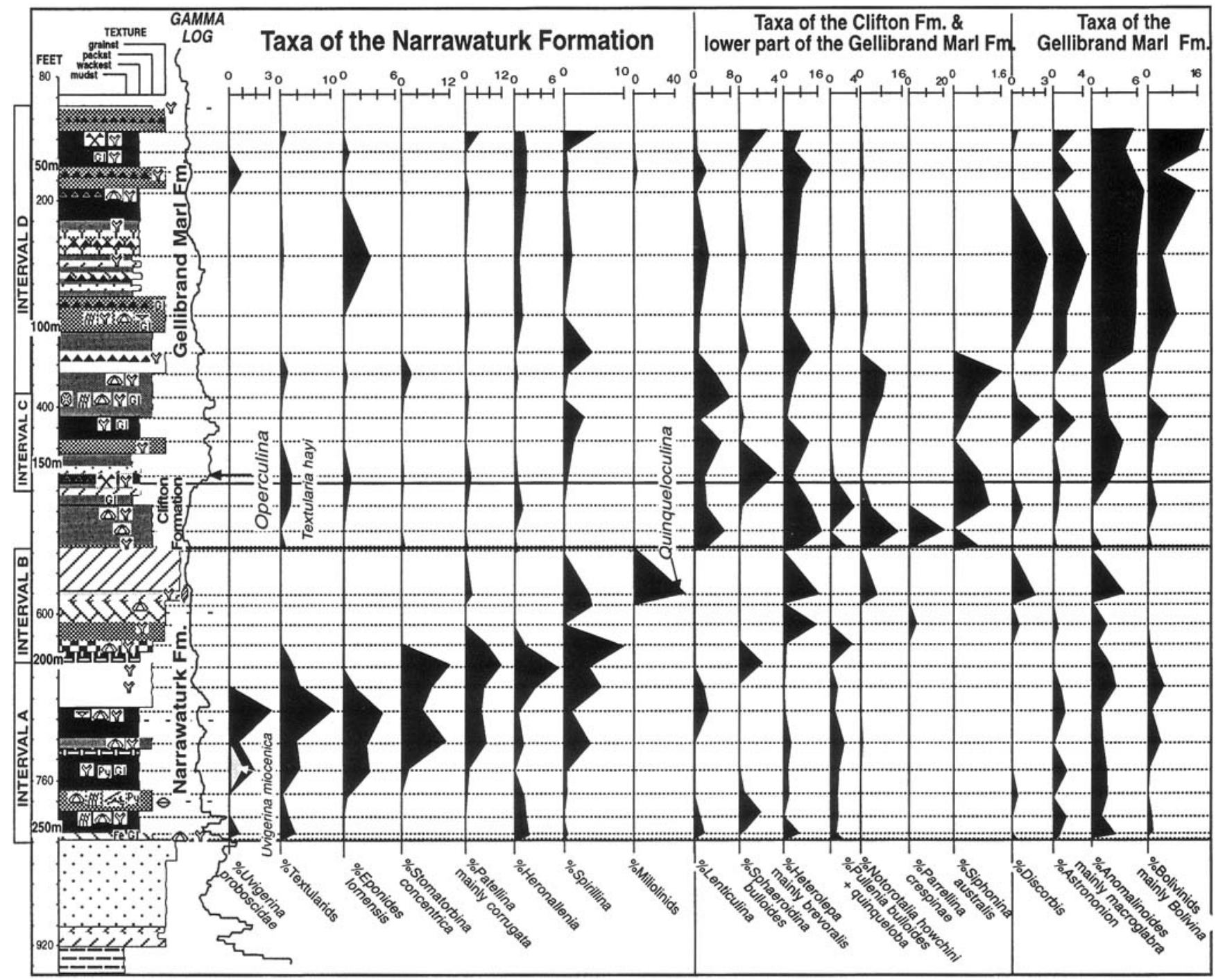

Fig. 7. Distribution of key benthonic foraminiferal taxa in the Glenelg-1 bore. Note: most values are expressed as a percentage of the total benthos. The miliolinids and textularids are expressed as percentages of the total fauna. See Appendices A and B for the faunal data. The log depths are in feet $(80-920 \mathrm{ft})$ and metres $(50-250 \mathrm{~m})$.

occur in the overlying units, although the diversity and plankton content increase markedly. The influx of planktonic foraminifera and the high-diversity assemblage above the basal grey marl suggests a lower energy open marine mid- to outer shelf palaeoenvironment established soon after the initial rapid transgressive event. From 720 to $689 \mathrm{ft}(219$ to $210 \mathrm{~m})$, Globocassidulina and Cibicidoides species are replaced upwards by common Uvigerina proboscidea and Eponides lornensis in the marl (both outer shelf taxa) alternating with peaks of Patellina and Spirillina (both inner shelf taxa) and Stomatorbina concentrica in the calcisiltite. These alternations of high- and low-energy carbonate facies may reflect storm layers and are probably also related to fluctuations in relative sea level. The peak of outer shelf taxa at $689 \mathrm{ft}(210 \mathrm{~m})$ may represent the deepest lowest energy shelf facies of the Narrawaturk Formation.

Most of the outer shelf foraminiferal taxa are not present in the chalky calcisiltite overlying the deepest marly facies in the upper part of this interval. These data, the low plankton values and the presence of common inner to middle shelf taxa (Spirillina and Patellina) indicate a higher energy shallow shelf palaeoenvironment. The lack of any clay/organic material in the chalk facies suggests that this facies represents an oligotrophic (nutrient-poor) palaeoenvironment.

Interval B: Facies. The facies in this interval are either partially or fully dolomitized. Samples containing fossils consist predominantly of recrystallized and partially dolomitized calcarenite or marly calcarenite (packstone to grainstone facies). The bioclast content varies according to the degree of dolomitization. Stick bryozoans are most common, with a reduced content of rounded regular echinoid spines and plates.

Interval B: Diagenetic alteration. Dolomitisation is partial 


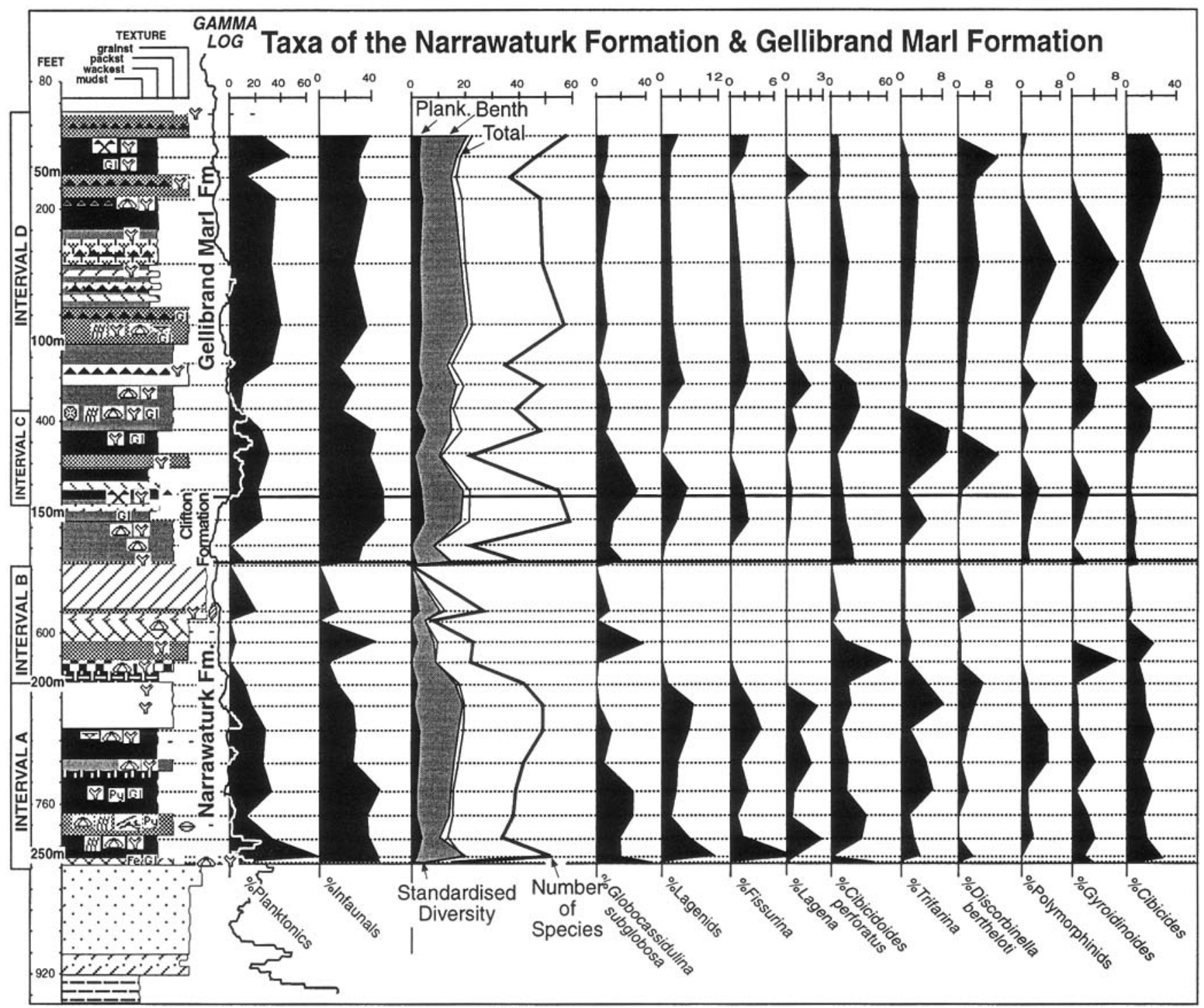

Fig. 8. Plankton percentage, faunal diversity and benthic foraminiferal distribution in the Glenelg-1 bore. The standardized diversity values were obtained by using the Margalef diversity calculation (from Brenchley \& Harper, 1998): diversity $=S-1 / \log N$, where $S=$ number of species and $N=$ number of specimens. Note: the benthic percentage values are expressed as a percentage of the total benthos. See Appendices A and B for the faunal data, where the epifaunal and infaunal benthic forms are listed. The log depths are in feet $(80-920 \mathrm{ft})$ and metres $(50-250 \mathrm{~m})$.

immediately above 640 feet (195 metres) and the percentage of dolomite increases to 536 feet (163 metres). The dolomite varies in grain size and colour from white fine-grained facies to coarse grained sucrosic light pink and red facies.

Interval B: Foraminifera. Foraminiferal diversity and relative abundance decreases markedly above $640 \mathrm{ft}(195 \mathrm{~m})$ in the Glenelg-1 bore (Fig. 8). The percentage of plankton and infaunal foraminifera also decrease upwards to $536 \mathrm{ft}(163 \mathrm{~m})$. Foraminiferal taxa abundant in the underlying marly and chalky facies are not common in this interval (with the exception of Patellina, Spirillina and Globocassidulina subglobosa). The marly calcarenite above 640 feet (195 metres) contains no planktonic foraminifera, up to 10\% Spirillina, 8\% Patellina and Gyroidinoides, with a high percentage of Cibicidoides perforatus. These taxa are rare in the overlying calcarenite that contains a fauna primarily of Globocassidulina subglobosa and Heterolepa brevoralis, with rare Discorbis and Parrellina crespinae (its first occurrence in the Glenelg-1 bore). Foraminifera are extremely rare or absent in the coarse, dolomitized facies above this level. The sample at $580 \mathrm{ft}$ yields a sparse fauna (only 120 specimens were obtained) that consists of over $50 \%$ milioliniids (Quinqueloculina sp., Q. cuvieriana, $Q$. laevigata and $Q$. vulgaris). Heterolepa brevoralis, Notorotalia, Discorbis and Anomalinoides also are common at this level.

Inverval B: Palaeoenvironment and Biofacies. With the exception of two samples, the primary lithologies of this interval have been partially or fully destroyed by dolomitization. Similar coarsegrained sucrosic dolomite is recorded in carbonates of the same 




Fig. 9. Depth distribution of modern foraminifera in southeastern Australia and New Zealand. The data were compiled from Vella (1962), Hayward (1990), Jones \& Yassini (1995) and Li et al. (1996a, 1996b).

age by James et al. (1993) in the adjacent Gambier Embayment in South Australia. James et al. (1993) suggest that the dolomite formed in the shallow subsurface after sediment deposition. Where preserved, the calcarenite (grainstone) facies with rounded grains and sorting is interpreted to have been deposited in a high-energy shelf setting. The lowermost sample contains a high proportion of inner shelf species with common mid- to outer shelf taxa, this apparent 'mixing' of different faunas, together with evidence of sorting at this level, suggests that the reworking of mid- to outer shelf faunas occurred in a shallow inner shelf setting. Alternatively, the inner shelf faunas may have been transported into a mid- to outer shelf setting. The fauna in the well-sorted bryozoal calcarenite facies above this sample at
$587 \mathrm{ft}(179 \mathrm{~m})$ is interpreted to have been deposited in a highenergy mid- to outer shelf palaeoenvironment. The sample at $578 \mathrm{ft}(176 \mathrm{~m})$ preserves a fauna typical of inner shelf palaeoenvironments (Quinqueloculina, Notorotalia and Discorbis) with lesser mid- to outer shelf taxa (Heterolepa and Anomalinoides) and probably represents the shallowest high-energy shelf facies in the Narrawaturk Formation.

\section{Clifton Formation}

Two sections of the Clifton Formation were studied: the type section near Port Campbell (Fig. 4) and a subsurface section in the Glenelg-1 bore (Figs 7 and 8 ) that can be identified using lithological and wireline characteristics. The two sections 
preserve quite different facies and foraminiferal assemblages.

Type section near Port Campbell: Facies. Medium-laminated, burrowed coarse-grained yellow, ferruginous calcareous sandstone comprises the Clifton Formation at this locality (Fig. 4). The dominant clasts are rounded quartz grains and calcareous fossils. One metre above the base of the section a prominent phosphate/limonite nodule horizon occurs in a matrix of calcareous sandstone. Bioclasts in this horizon include foraminifera, stick bryozoa, regular echinoid spines, gorgonacian corals and ferruginized gastropods. A bioturbated pectinid shell band overlies the nodular bed. Small nodules of phosphate and limonite occur in the calcareous sand matrix of this band. The bioclast content is similar to that of the phosphatic horizon.

Type section near Port Campbell: Foraminifera. Planktonic foraminifera (Fig. 4) are relatively uncommon in the Clifton Formation outcrop (15-16\% peaking at $24 \%$ at the nodule band, Fig. 4 and Appendix C). The lowermost sample yielded a low diversity fauna rich in Cibicidoides perforatus, Heterolepa brevoralis, Cibicides mediocris and C. lobatulus. Other important components include Cassidulina laevigata and Bolivina with a single occurrence of the 'large' foraminifer Planorbulinella johannae. Faunal diversity and abundance increase (see Appendix 1) above this horizon, associated with a reduction in the abundance of $C$. laevigata, $H$. brevoralis and $C$. perforatus. Taxa that occur in all samples from the nodular band up-section include: C. mediocris, Cassidulinoides chapmani, Cibicides vortex, Discorbis balcombensis, Notorotalia and textulariids such as Dorothia minima. Rare, poorly preserved specimens of Pararotalia mackayi occur in the upper two samples of the Clifton Formation.

Type section near Port Campbell: Palaeoenvironment and Biofacies. The medium- to coarse-grained calcareous sandstones of the Clifton Formation type section are interpreted to have formed in high-energy shelf palaeoenvironments where a high clastic input impeded carbonate deposition. The phosphate/ limonite nodular band represents a hardground surface caused by non-deposition in a shelf environment, probably over a considerable period of time. The nodular band may therefore represent a hiatus due to a regressive event. The overlying shell band and the sediment in the matrix of the nodular band may have been a lag deposit on top of this surface. Reworking of the nodular horizon has occurred and is preserved in the strata above this level.

The assemblage in the lowermost sample is interpreted to have been deposited in a mid- to outer shelf palaeoenvironment; the presence of Planorbulinella may possibly suggest a subtropical influence to the fauna at this level. The assemblages in the overlying units are very similar and consist predominantly of inner to mid-shelf foraminifera. The slight peak in planktonic abundance in the matrix of the phosphate may have been caused by a slightly cooler upwelling palaeoenvironment at that time and/or the assemblage accumulated over a long period of time and was 'time-averaged'.

Clifton Formation in Glenelg-1. The Clifton Formation occurs above the dolomite of the Narrawaturk Formation and below the gamma pick at 476 feet (145 metres, Figs $7,8,9)$. Three samples were studied in this interval.

Clifton Formation in Glenelg-1: Facies. The lowermost sample of the Clifton Formation in the Glenelg-1 bore is a white to grey calcarenite/calcisiltite (grainstone/packstone) with abundant (often rounded) bioclasts of stick bryozoa, gastropods and regular echinoid spines (Fig. 6). Rare glauconite pellets, dolomite fragments and limonite nodules occur. The overlying sample is a white, echinoderm-rich calcisiltite (packstone). The regular echinoid fragments in this sample have been rounded and sorted, ranging in size from 0.1 to $2 \mathrm{~mm}$. The overlying sample at $494 \mathrm{ft}(150.6 \mathrm{~m})$ is a white, bryozoan- and regular echinoid-rich calcisiltite (packstone). The bioclasts in this sample are not rounded or sorted, although rare glauconite peloids do occur.

Clifton Formation in Glenelg-1: Foraminifera. The first calcarenite/calcisiltite sample of this unit has a foraminiferal assemblage dominated by relatively large specimens $(>1 \mathrm{~mm})$ of $G$. subglobosa and $C$. perforatus. The foraminiferal diversity and plankton content of this sample is relatively low (compared with other intervals in Glenelg-1; Figs 7 and 8). Planktonic foraminifera are absent in the overlying sample, where the benthos is dominated by a low diversity assemblage consisting of Heterolepa brevoralis, Notorotalia, Lenticulina and Parrellina crespinae. Planktonic foraminifera become abundant and diverse in the upper sample of the Clifton Formation associated with an increase in the benthonic Cassidulinoides chapmani and Pullenia ( $P$. bulloides and $P$. quinqueloba), with common $H$. brevoralis.

Clifton Formation in Glenelg-1: Palaeoenvironment and Biofacies. The fauna and facies in the lowermost grey to white sample is interpreted to have been deposited in a high-energy shelf palaeoenvironment, where much of the planktonic and other smaller foraminifera were winnowed away, leaving a relatively low-diversity large benthic fauna. The fauna and facies are very similar to those of the initial facies of the Narrawaturk Formation (see earlier), where upwelling in an inner shelf palaeoenvironment may have occurred during the transgressive phase of the unit. The presence of limonite nodules and glauconite pellets with dolomite clasts in this sample probably represents reworking of a hardground surface that may have developed over the underlying dolomite. This suggests a hiatus occurred at the Narrawaturk Formation-Clifton Formation boundary, possibly caused by a regressive event, that was followed by a rapid transgression to establish shelf conditions. The overlying sample is also interpreted to have been deposited in high-energy shelf conditions. The dominant benthic foraminifera in this sample typify inner to mid-shelf depths. It is likely that winnowing has removed much of the plankton and other foraminifera in this sample. The upper calcisiltite sample of the Clifton Formation preserves a mid- to outer shelf fauna that was probably deposited in relatively lower energy conditions than those of the lower part of the Clifton Formation.

Gellibrand Marl Formation

The Gellibrand Marl Formation overlies the Clifton Formation. 
As its name suggests, marl dominates the facies, although calcisiltite and calcarenite also occur. Based on facies and microfauna, the Gellibrand Marl Formation can be subdivided into two sections (Fig. 7): Interval C [479-390 ft (146-119 m)] and Interval D [389-108 ft (118.5-33 m)].

Interval C: Facies. Grey stick bryozoal marl (wackestone) alternates with light yellow calcisiltite (packstone). The first cherty facies that may contain fine-grained rhombs of dolomite occurs at the base in a sponge spicule-rich bryozoal marl. The light yellow calcisiltite at $390 \mathrm{ft}(119 \mathrm{~m})$ contains glauconite and limonite-stained bioclasts of large, rounded, regular echinoid spines (up to $5 \mathrm{~mm}$ ), stick bryozoa and gorgonacean corals.

Interval C: Foraminifera. The basal marl preserves a high diversity planktonic and benthonic foraminiferal assemblage (Figs 7 and 8) with common G. subglobosa and Sphaeroidina bulloides. Above this, Heterolepa, Lenticulina and Anomalinoides become common elements in the assemblages. Discorbis, Notorotalia and Cibicides increase in abundance up to $390 \mathrm{ft}$ $(119 \mathrm{~m})$, associated with a reduction in G. subglobosa, Sphaeroidina and Anomalinoides. The plankton and infaunal component also decreases markedly at $390 \mathrm{ft}(119 \mathrm{~m})$.

Interval C: Palaeoenvironment and Biofacies. The cherty bryozoal marl at the base is interpreted to have been deposited in a low-energy outer shelf palaeoenvironment based on its fauna and facies. The fauna in the overlying bryozoal marl and calcisiltite was probably deposited in low- to slightly higher energy mid- to outer shelf palaeoenvironments. The change in fauna at $390 \mathrm{ft}(119 \mathrm{~m})$ coincides with a marked facies change. At this level, inner to mid-shelf foraminifera replace the mid- to outer shelf faunas. This change is accompanied by limonitestained high-energy facies. The presence of glauconite and gorgonacean corals is interpreted to represent the presence of a hardground that formed during a hiatus due to a sea-level fall. This sea-level fall may have lead to subaerial exposure as limonite staining is pervasive at this level.

Interval D: Facies. Cherty grey bryozoal marl typical of the Gellibrand Marl Formation dominates the upper part of this interval (Fig. 7), with occasional cemented calcarenite (grainstone) beds, many of which are partially dolomitized. Cherty packstone to grainstone facies occur towards the base. The lowermost sample is a white, stick bryozoan and regular echinoid-rich calcisiltite (packstone). The echinoderm bioclasts are rounded. White, cherty stick bryozoal chalk (wackestone) and echinoid-rich calcarenite (grainstone) facies occur above this basal sample. The chert bands in the white limestone exposed along Glenelg Gorge (Figs 1 and 3.1) are likely to be equivalent to cherty calcisiltites in this interval.

Interval D: Foraminifera. With the exception of the basal sample and at $172 \mathrm{ft}(52 \mathrm{~m})$, infaunal and planktonic foraminifera are abundant (Figs 7 and 8) and Anomalinoides, Bolivina, Astrononion and Cibicides increase upwards from this sample. Gyroidinoides allani and Cibicidoides perforatus are common in the lower part and Notorotalia occurs only in the lowermost sample. Eponides lornensis co-occurs with a peak in abundance of Discorbis in the marly facies at $253 \mathrm{ft}$ (77 metres).

Interval D: Palaeoenvironment and Biofacies. The lower sorted plankton- and infaunal-poor calcisiltite is interpreted to have been deposited in a high-energy mid-shelf palaeoenvironment. The units immediately overlying this horizon possibly represent deeper mid- to outer shelf high-energy facies, which were in turn followed by outer shelf low-energy bryozoal marly facies with occasional higher energy events depositing beds of calcarenite. The presence of the inner to mid-shelf taxon Discorbis within an interpreted outer shelf assemblage may reflect reworking, perhaps by bioturbation, or reflect the outermost shelfal limit of this taxon.

\section{OLIGO-MIOCENE PALAEOENVIRONMENTAL EVOLUTION}

The three units studied contain variable facies and foraminiferal assemblages, preserving very different palaeoenvironmental signatures (Fig. 10).

From the base of the Narrawaturk Formation to $540 \mathrm{ft}$ $(164.5 \mathrm{~m})$, initial transgressive high-energy, inner shelf, mixed carbonate/clastic facies (with evidence of possible upwelling) were followed immediately by low-energy mid- to outer shelf marly palaeoenvironments (Fig. 10). There is evidence for upsection deepening to an outer shelf palaeoenvironment at $689 \mathrm{ft}$ $(210 \mathrm{~m})$ alternating with higher energy facies reflecting storm events or minor shallowing intervals. The next unit, consisting of chalky facies, was deposited in an oligotrophic higher energy, inner shelf palaeoenvironment. A return to lower energy shelf marly facies followed the chalky facies (this interval was not sampled). The uppermost beds in the Narrawaturk Formation were deposited in high-energy shelf settings with mixing of inner and mid- to outer shelf taxa due to reworking or transportation. Most of the preserved fauna is likely to have been deposited in an inner shelf palaeoenvironment, with the exception of the midto outer shelf palaeoenvironment interpreted for the horizon at $587 \mathrm{ft}(179 \mathrm{~m})$. Most of the primary lithofacies in the upper part of the Narrawaturk Formation have been obliterated by postdepositional dolomitization.

The two sections of the Clifton Formation studied were deposited in relatively high-energy shelf palaeoenvironments in areas with contrasting terrestrial inputs. Clastic sediments dominate facies of the Clifton Formation near Port Campbell, whereas no clastics occur in this unit in the Glenelg-1 bore. Diverse inner to mid-shelf foraminiferal faunas dominate both sections, with occasional mid- to outer shelf faunas and evidence of regressive events. The base of the Clifton Formation in Glenelg-1 overlies a hiatus caused by an inferred sea-level fall (Fig. 10). A similar event is represented by a nodular horizon in the Clifton Formation type section (Figs 3 and 4).

The first low-energy outer shelf cherty bryozoal marl occurs at the base of the Gellibrand Marl Formation in the Glenelg-1 bore (Fig. 10). Following this, mid- to outer shelf calcisiltite and lowenergy marl facies were deposited. A significant facies change at $390 \mathrm{ft}(119 \mathrm{~m})$ corresponds to a 'switch' to inner to mid-shelf faunas in a high-energy palaeoenvironment, accompanied by a hiatus that led to hardground formation and perhaps even subaerial exposure. High-energy mid- to outer shelf conditions 


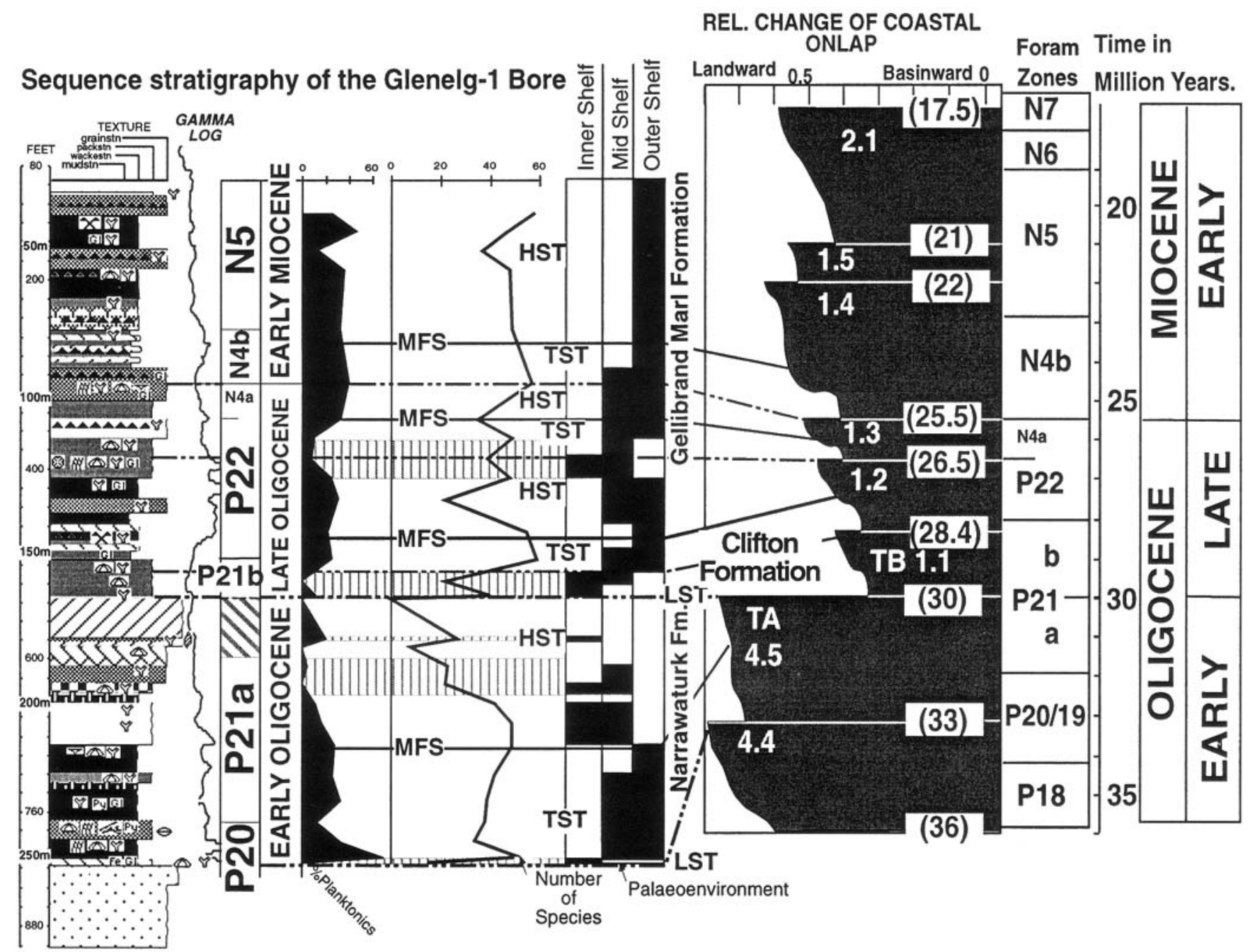

Fig. 10. Sequence stratigraphy and palaeoenvironmental evolution of the Oligo-Miocene cool-water carbonates in the Glenelg-1 bore. The vertical hatch intervals are horizons where significant reworking and sorting of the microfauna has occurred. The total number of species is illustrated. The sea-level curve is adapted from Haq et al. (1988). The log depths are in feet $(80-920 \mathrm{ft})$ and metres $(50-250 \mathrm{~m})$.

became established after this hiatus. Further deepening occurred, depositing lower energy outer shelf cherty marl in the upper part of the Gellibrand Marl Formation.

\section{OLIGO-MIOCENE SEQUENCE BIOSTRATIGRAPHY}

The strata of the Glenelg-1 bore are correlated biostratigraphically with the relative change of coastal onlap of Haq et al. (1988) in Fig. 10. While acknowledging that the section in Glenelg-1 is likely not to preserve strata representing the full duration of the Oligo-Miocene, it is possible to assign sequences to particular intervals based on biostratigraphic, palaeoenvironmental and sedimentological considerations. In addition, it is possible to recognize biofacies reflecting probable lowstand system tracts (LSTs), maximum flooding surfaces (MFSs) and highstand systems tracts (HSTs). These sequences are described in the following sections.
Narrawaturk Formation: Early Oligocene sequence TA 4.5

This unit rests unconformably on the Late Eocene Mepunga Formation in the Glenelg-1 bore, but elsewhere it overlies the Wangoom Sand Member of Early Oligocene (P18) age (Fig. 2). The thin basal bed of the Narrwaturk Formation has a sorted inner shelf foraminiferal fauna and probably represents a lag deposit, and is interpreted to be the LST of the sequence. Transgressive middle to outer shelf marl and calcisiltite follow, culminating in outer shelf bryozoal marl, with the highest foraminiferal diversity at the MFS of this sequence. Inner to mid-shelf calcisiltite and calcarenite (often strongly dolomitized) typify the HST deposit of this sequence.

The Clifton Formation: Late Oligocene sequences $T B 1.1$ and $T B$ 1.2

The surface on top of the dolomites of the Narrawaturk Formation is inferred to be a sequence boundary, correlating with the major Middle Oligocene global sea-level shift at the $T A$ 

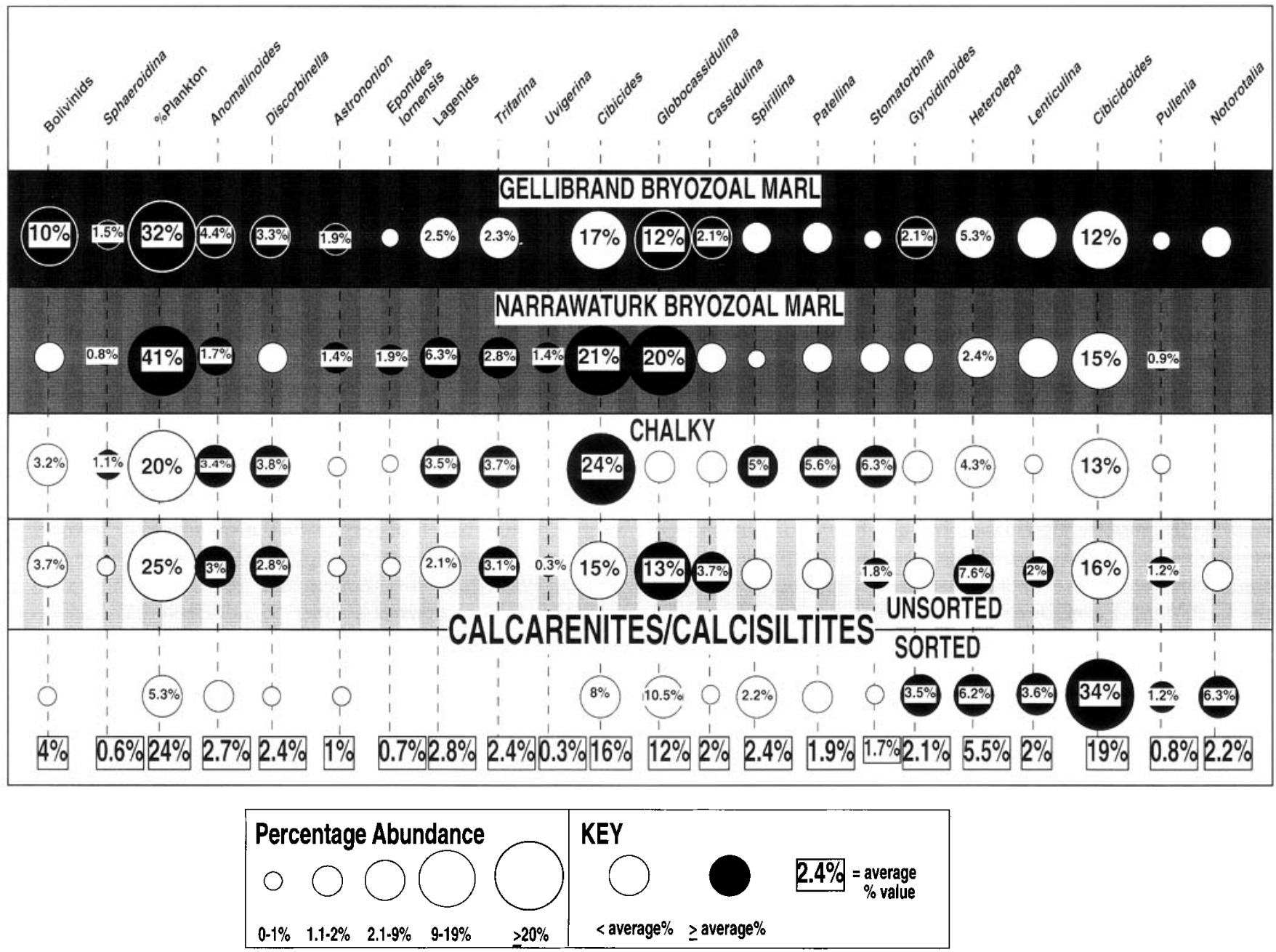

Fig. 11. Biofacies distribution of foraminifera in the Oligo-Miocene succession studied. Note: the plankton values are expressed as a percentage of the total foraminiferal fauna; all other taxa are expressed as a percentage of benthonic rotaliids. The values at the base of the figure are the average faunal percentage values for that particular foraminifer in the 25 samples studied quantitatively. The circles show the average percentage values for that taxon in each particular facies. The white circles denote percentage values below average abundance and the black circles are equal to or above average values. For example, bolivinids are abundant in the Gellibrand bryozoal marls ( $10 \%$ of the assemblage) and rare in all other facies (below the average of $4 \%$ ).

4.5/TB 1.1 boundary. The reworked facies at the base of the Clifton Formation are interpreted to be possible LST deposits. The sampling density in this study is not sufficient to identify different systems tracts within the $T B \quad I . I$ sequence. The phosphate nodule band at Clifton Beach (Fig. 4) corresponds closely to the $\mathrm{P} 21 \mathrm{~b} / \mathrm{P} 22$ zonal boundary. This horizon is interpreted to reflect a hiatus and is possibly the $T B 1.1 / T B$ 1.2 sequence boundary. The Late Oligocene $\mathrm{P} 21 \mathrm{~b} / \mathrm{P} 22$ zonal boundary in this unit in the Glenelg-1 bore corresponds with a marked shift in foraminiferal biofacies, also marking the top of sequence $T B$ 1.1.

Gellibrand Marl Formation: sequences $T B \quad 1.2, T B I .3$ and $T B$ $1.5 / 2.1$

Transgressive mid- to outer shelf calcisiltite of sequence $T B \quad 1.2$ deepens upwards to the first outer shelf cherty marl at the base of the Gellibrand Marl Formation, preserving the MFS of the sequence. Alternations of mid- to outer shelf marl, calcisiltite and calcarenite form the HST of this sequence. A hiatus inferred on facies data forms the upper boundary of sequence $T B$ 1.2. Sequence $T B 1.3$ consists predominantly of mid- to outer shelf calcisiltite and calcarenite facies. The upper boundary is tentatively placed at the first appearance of the Early Miocene taxon $G$. woodi, in the absence of any clear evidence of a hiatus. The succeeding sequence $T B 1.3$ yields evidence of progressive deepening upwards from a mid- to outer shelf cherty calcarenite (TST) to outer shelf cherty facies (MFS/HST).

\section{DISCUSSION}

Facies control on Palaeogene-Neogene cool-water foraminiferal assemblages

Four principal biofacies types were identified in this study (Fig. 11), with distinctive foraminiferal assemblages that relate to factors such as depth, wave energy and substrate. 
Bryozoal marl. Grey bryozoal marl (wackestone) is one of the most common facies in the Oligo-Miocene strata studied. It is inferred to have formed in mid- to outer shelf low-energy palaeoenvironments with fine substrates that favoured infaunal foraminifera and high plankton values. Although the marly facies are similar between the Gellibrand Marl and the Narrawaturk Formations, both units contain different microfaunal assemblages and some important macroscopic differences. The Gellibrand Marl Formation facies are cherty and spicule-rich and contain abundant bolivinids, with common Astrononion and Anomalinoides (Fig. 11). In contrast, bolivinids are rare or absent in the Narrawaturk Formation marls, where chert and spicules are also absent. In this unit, the infaunal Uvigerina, Globocassidulina and lagenids are common. The difference in microfaunal content in the grey bryozoal marl of the two units may relate to: (a) variations in organic material and fossil sponge content in the marly substrate between the units (it is possible that anaerobic conditions or eutrophism persisted in Narrawaturk times and by Gellibrand times conditions were more open marine); (b) the cherty marls of the Gellibrand Formation may have been deposited in deeper outer shelf palaeoenvironments than those in the Narrawaturk Formation; (c) benthos turnover across the early-late Oligocene boundary; or (d) a combination of all of these factors. Bryozoal marls similar to these which are preserved in the Oligocene carbonates of the Torquay area in Victoria are interpreted by Boreen \& James (1995) to have been deposited in deep shelf, quiet water palaeoenvironments near the storm wave-base. The storm wave-base off the Otway shelf margin today is at around $250 \mathrm{~m}$ (Boreen et al., 1993), it is unlikely that the depth to storm wave-base during Oligo-Miocene times was the same as today, as the width (and therefore the fetch) of the Southern Ocean was not as large. Therefore, the storm wave-base was probably shallower.

Chalky facies. White, bryozoal chalky packstone occurs at several levels in the Glenelg-1 bore. This facies is interpreted to have been deposited in inner to outer shelf palaeoenvironments and contains a distinctive microfauna of the epifaunal Cibicides, Spirillina, Stomatorbina and Patellina, with the infaunal Trifarina. Moderate to low percentages of plankton occur. The prevalence of epifauna (such as Cibicides) and lack of plankton in this facies is inferred to reflect a low nutrient supply during deposition. The chalky substrate was suitable for low amounts of infauna such as Trifarina, but not for the bolivinids or Uvigerina (these taxa may prefer organic-rich or clay-rich substrates). Moderate reworking of this facies may have occurred, removing the organic material and some of the smaller foraminifera.

Unsorted calcisiltite and calcarenite. Light grey, yellow and white bryozoan-poor foraminiferal packstone and grainstone deposited in inner to outer shelf palaeoenvironments typify this facies. No obvious rounding or sorting of the bioclasts has occurred. With the exception of Globocassidulina and Trifarina, infaunal foraminifera are rare. Epifaunal foraminifera such as Heterolepa, Cassidulina and Anomalinoides are common. The variation in foraminiferal content (Fig. 11) and colour of this facies probably reflects fluctuations in wave energy and/or clay and organic content in the substrate at the time of deposition. Similar mixed grainstone and packstone facies in the Oligocene succession of Torquay, Victoria are thought to have been midto deep shelf storm and fairweather sediments deposited between swell wavebase and storm wavebase (Boreen \& James, 1995). Storm wave-base and swell wave-base off the Otway coast today are around $250 \mathrm{~m}$ and $130 \mathrm{~m}$, respectively (Boreen et al., 1993). Based on palaeoceanogeographical considerations these depths to wave-base are likely to have been shallower during OligoMiocene times.

Sorted calcisiltite and calcarenite. White to yellow coarse-grained regular echinoid- and bryozoan-rich packstone to grainstone characterise this facies. Appreciable rounding and sorting of the bioclasts has occurred, leading to the preservation of robust spherical to discoidal epifaunal foraminifera such as Cibicidoides, Heterolepa, Pullenia, Gyroidinoides and Notorotalia. The spherical infaunal Globocassidulina also survived reworking. Other less robust infaunal and epifaunal foraminifera are rare or absent. Planktonic foraminifera are also rare. This facies is interpreted as representing inner to mid-shelf palaeoenvironments where reworking by intense wave action (either above normal wavebase or by storms) sifted out all smaller foraminifera. This process favoured the preservation of the hydrodynamically stable foraminifera (spherical/discoidal) and created a substrate unsuitable for delicate infaunal foraminifera. Crossbedded bryozoan grainstones (resembling this facies) in the Oligocene strata of Torquay, Victoria are interpreted by Boreen \& James (1995) to be open-shelf sands deposited during highenergy swell/storm wave-base reworking.

Global correlations, palaeoceanography and relative sea-level changes

The neritic sediments of the Glenelg-1 bore and outcrops of the Clifton Formation near Port Campbell in southeastern Australia preserve biofacies signals relating to the evolution of the Southern Ocean at the Palaeogene/Neogene boundary (Fig. 1). Specifically, the base of the Clifton Formation preserves a shift in facies and foraminiferal faunas that correlates with the major sea-level fall at the mid-late Oligocene boundary (Haq et al., 1988). It is well known that this sea-level fall is related to a major ice advance in Antarctica (Kennett, 1977; Prothero, 1994) which corresponds to Mid-Oligocene unconformities globally (Poag \& Ward, 1987). The effects of this event have been documented by Moss \& McGowran (1993) in South Australia, where biofacies changes occur without any appreciable species turnover in the Early-Late Oligocene neritic sediments of the Gambier Embayment of the Otway Basin. Moss \& McGowran (1993) noted that plankton and infaunal percentages decrease and notorotaliids first appear at the Early--Late Oligocene boundary in the Gambier Embayment; a similar pattern occurs in the Glenelg1 bore (Fig. 1). Other events occurring across the Early-Late Oligocene boundary in the Glenelg-1 bore (Figs 6-8) include: the LADs of $S$. linaperta, $T$. gemma and $C$. cubensis; a reduction in Globoturborotalia and Paragloborotalia associated with an increase in Globigerina; a reduction in benthic taxa such as Uvigerina, Textulariids, Stomatorbina, Patellina, Heronallenia and Spirillina; and increases in Heterolepa, Siphonina, Discorbis, 
Anomalinoides, Cibicides and bolivinids.

The biostratigraphic and palaeoenvironmental utility of these Southern Ocean Tertiary cool-water foraminiferal assemblages is enhanced greatly by parallel facies studies. An integration of biostratigraphic and facies data will lead to better stratigraphic correlations and palaeoenvironmental interpretations of strata in southeastern Australia, an area that was facing the evolving Southern Ocean throughout the Cenozoic.

\section{CONCLUSIONS}

This study integrates biofacies and foraminiferal analyses of an Oligocene to Miocene cool-water carbonate succession in the Otway Basin, southeastern Australia to conclude the following.

(1) The Early Oligocene Narrawaturk Formation consists initially of high-energy inner shelf facies and deepens gradually up-section to lower energy mid- to outer shelf marls with storm events and/or minor shallowing intervals. The uppermost bed of this unit was deposited in a high-energy shelf setting with faunal reworking.

(2) The Late Oligocene Clifton Formation was deposited in a relatively high-energy inner to mid-shelf environment. Clastic sedimentation dominated in the eastern Otway Basin, whereas no clastics occur in this unit in the west. The base of this unit overlies a hiatus (a phosphate horizon) inferred to have been caused by a sea-level fall.

(3) The Late Oligocene Gellibrand Marl Formation began with low-energy outer shelf cherty bryozoal marl followed by mid- to outer shelf calcisiltite. High-energy mid- to outer shelf conditions were established after a hiatus in the latest Oligocene. Deepening at the base of the early Miocene, caused deposition of lower energy outer shelf cherty marl.

(4) Oligo-Miocene strata are correlated with the relative coastal onlap curve of Haq et al. (1988) and several sequences (including their LSTs, TSTs, MFSs and HSTs) can be identified. The Narrawaturk Formation correlates with sequence $T A 4.5$. The TST of this sequence preserves mid- to outer shelf marl and calcisitite, the MFS high plankton values and inner to mid-shelf calcisiltite and calcarenite represent the HST. The Clifton Formation correlates with sequences $T B$ I.I and $T B$ 1.2. The phosphate nodule band in this unit probably marks the $T B \quad 1.1 / T B \quad 1.2$ sequence boundary. The Gellibrand Marl Formation correlates to sequences $T B 1.2, T B 1.3$ and $T B$ 1.5/2.1.

(5) Four major carbonate facies with distinctive foraminiferal faunas can be distinguished. Grey bryozoal marl (wackestone) formed in mid- to outer shelf low-energy conditions below the wave-base, with infaunal foraminifera and high plankton values. Two marl assemblages occur: lagenids and Uvigerina are common in the Narrawaturk marl, abundant bolivinids and Astrononion occur in the Gellibrand marl. The variation is thought to relate to varying nutrient supply and organic material, depth or benthos turnover at the Early-Late Oligocene boundary. Chalky packstone facies were deposited in oligotrophic inner to mid-shelf palaeoenvironments and contain a high epifauna content. A bryozoan-poor foraminiferal packstone and grainstone (calcisiltite/ calcarenite) facies enriched in epifaunal foraminifera is inferred to have been deposited in inner to outer shelf palaeoenvironments. The final facies type consists of well-sorted, coarse-grained regular echinoid- and bryozoan-rich packstone to grainstone (calcisiltite/calcarenite). Infauna is absent in this facies, where most preserved foraminifera are robust spherical to discoidal forms. These facies were deposited in inner to mid-shelf palaeoenvironments where reworking by intense wave action (either above normal wave-base or by storms) winnowed out all smaller foraminifera.

(6) The strata preserve biofacies signals relating to the evolution of the Southern Ocean at the PalaeogeneNeogene boundary. The base of the Clifton Formation marks a shift in facies and foraminiferal faunas that correlates to the major-sea level fall at the Mid-Late Oligocene boundary, related to a probable major ice advance in Antarctica during this time. The base of this unit also correlates with Mid-Oligocene unconformities worldwide.

(7) The stratigraphic and palaeoenvironmental utility of these cool-water foraminiferal assemblages is improved greatly by facies analyses. Similar integrated studies will lead to better correlations and palaeoenvironmental interpretations of southeastern Australian strata and contiguous strata in the southern hemisphere.

\section{ACKNOWLEDGEMENTS}

This study was supported by a grant from the Australian Research Council. The authors thank two anonymous referees whose constructive comments greatly improved the manuscript. We thank Brian McGowran and Pat Quilty for providing helpful comments and edits on an earlier draft of the text.

\section{Manuscript received 1 October 1998 Manuscript accepted 10 April 1999}

\section{REFERENCES}

Boreen, T. D. \& James, N. P. 1995. Stratigraphic sedimentology of Tertiary cool-water limestones, SE Australia. Journal of Sedimentary Research, B65(1): 142-159.

Boreen, T., James, N. P., Heggie, D. \& Wilson, C. 1993. Surficial coolwater carbonate sediments on the Otway continental margin, southeastern Australia. Marine Geology, 112: 35-56.

Brenchley, P. J. \& Harper, D. A. T. 1998. Palaeoecology: Ecosystems, Environments and Evolution. Chapman and Hall London: $402 \mathrm{pp}$.

Crespin, I. 1954. The Nelson Bore, south-western Victoria, micropalaeontology and stratigraphical succession. Bureau of Mineral Resources, Geology and Geophysics, Report No. 11: 1-39.

Haq, B. U., Hardenbol, J. \& Vail, P. R. 1988. Mesozoic and Cenozoic chronostratigraphy and cycles of sea-level change. In: Wilgus, C. K., Hastings, B. S., Kendall, C. G. St. C., Posamentier, H. W., Ross, C. A. \& Van Wagoner, J. C. (Eds), Sea-level Changes: an Integrated Approach. Special Publication of the Society of Economic Paleontologists and Mineralogists, 52: 71-109.

Hayward, B. W. 1990. Use of foraminiferal data in the analysis of Taranaki Basin, New Zealand. Journal of Foraminiferal Research, 20: $71-83$.

Holdgate, G. R. \& Gallagher, S. 1997. Microfossil paleoenvironments and sequence stratigraphy of Tertiary cool-water carbonates, onshore Gippsland Basin, SE Australia. In: James, N. \& Clarke J. (Eds), Cool and Temperate Water Carbonates, Special Publication of the Society of 
Economic Palaeontologists and Mineralogists, 56: 205-220.

James, N. 1997. The cool-water carbonate depositional realm. In: James, N. \& Clarke J. (Eds), Cool and Temperate Water Carbonates, Special Publication of the Society of Economic Palaeontologists and Mineralogists, 56: 1-20.

\section{HERE}

James, N., Bone, Y. \& Kyser, T.K. 1993. Shallow burial dolomitization and dedolomitization of mid-Cenozoic, cool-water, calcitic, deepwater limestones, southern Australia. Journal of Sedimentary Petrology, 63: 528-538.

Jones, B. G. \& Yassini, I. 1995. Foraminiferida and Ostracoda from Estuarine and Shelf Environments on the Southeastern Coast of Australia. The University of Wollongong Press: $484 \mathrm{pp}$.

Kennett, J. P. 1977. Cenozoic evolution of Antarctic glaciation, the circum-Antarctic Ocean, and their impact on global paleoceanography. Journal of Geophysical Research, 82: 3843-3860.

Kennett, J. P. \& von der Borch, C. C. 1986. Southwest Pacific Cenozoic paleoceanography. Initial Reports of the Deep Sea Drilling Project, 90(2): 1493-1517.

Lindsay, J. M. 1985. Aspects of southern Australian foraminiferal biostratigraphy, with emphasis on studies of Massilina and Subbotina. In: Lindsay, J. M. (Ed.), Stratigraphy, Palaeontology, Malacology, Papers in Honours of Dr Nell Ludbrook. Department of Mines and Energy, Adelaide, Special Publication, 5: 183-214.

Li, Q., McGowran, B., James, N., Bone, Y. \& Cann, J. 1996a. Mixed foraminiferal biofacies on the mesotrophic, mid-latitude Lacepede Shelf, South Australia. Palaios, 11: 176-191.

Li, Q., MeGowran, B., James, N., Bone, Y. \& Cann, J. $1996 \mathrm{~b}$. Foraminiferal biofacies on the mid-latitude Lincoln Shelf, South Australia: oceanographic and sedimentological implications. Marine Geology, 129: 285-312.

Ludbrook, N. H. 1971. Stratigraphy and correlation of marine sediments in the western part of the Gambier Embayment. In. Wopfner, H. \& Douglas, J. G. (Eds), The Otway Basin in Southeastern Australia. Adelaide and Melbourne, Geological Surveys of Southern Australia and Victoria, Special Bulletin: 241-261.

McGowran, B. 1973. Observation bore No. 2, Gambier Embayment of the Otway Basin: Tertiary micropalaeontology and stratigraphy. Mineral Resources Review, South Australia, 135, 43-55.

McGowran, B., Li, Q. \& Moss, G. 1997. The Cenozoic neritic record in southern Australia: the biogeohistorical framework. In: James, N. \& Clarke J. (Eds), Cool and Temperate Water Carbonates, Special Publication of the Society of Economic Palaeontologists and Mineralogist, 56: $185-203$.

Moss, G. \& McGowran, B. 1993. Foraminiferal turnover in neritic environments: the end-Eocene and mid-Oligocene events in southern Australia. Memoirs of the Association of Australasian Paleontologists, 15: $407-416$.
Murray, J. W. 1991. Ecology and Paleoecology of Benthic Foraminifera. Longman Scientific and Technical, London: $274 \mathrm{pp.}$

Poag, C. W. \& Ward, L. W. 1987. Cenozoic unconformities and depositional supersequences of the North Atlantic continental margins: testing the Vail model. Geology, 15: 159-162.

Prothero, D. R. 1994. The late Eocene-Oligocene extinctions. Annual Review of Earth and Planetary Science, 22: 145-165.

Veevers, J. J., Powell, C. M. \& Roots, S. R. 1991. Review of seafloor spreading around Australia. 1. Synthesis of the patterns of spreading. Australian Journal of Earth Sciences, 38: 373-389.

Vella, P. 1962. Determining depths of New Zealand Tertiary seas. Tuatura, 10: 19-40.

\section{APPENDIX A}

This Appendix gives a list of the foraminifera in the Glenelg-1 bore. The inferred infaunal (i) and epifaunal (e) benthonic forms are listed in the lefthand column, where there is no designation (i.e. a blank) the benthonic habit of that particular foraminifer is unknown. The foraminiferal habits were classified using Murray (1991) and Moss \& McGowran (1993). Note that the sample at $587 \mathrm{ft}(179 \mathrm{~m})$ was statistically too small to be included in percentage values in Figs 7, 8 and 10, although the number of species and species diversity data were used in Figs 8 and 10.

\section{APPENDIX B}

Foraminiferal percentage data for the Glenelg-1 bore. The benthos values are calculated as a percentage of the total benthic rotaliids. The plankton values are expressed as a percentage of the plankton.

\section{APPENDIX $C$}

List of the foraminifera and their percentage values in the Clifton Formation type section, near Port Campbell (Fig. 4). The sample numbers 1 to 4 are those illustrated on the logged section on Fig. 4. The benthos values are calculated as a percentage of the total benthic rotaliids. The plankton values are expressed as a percentage of the plankton. 


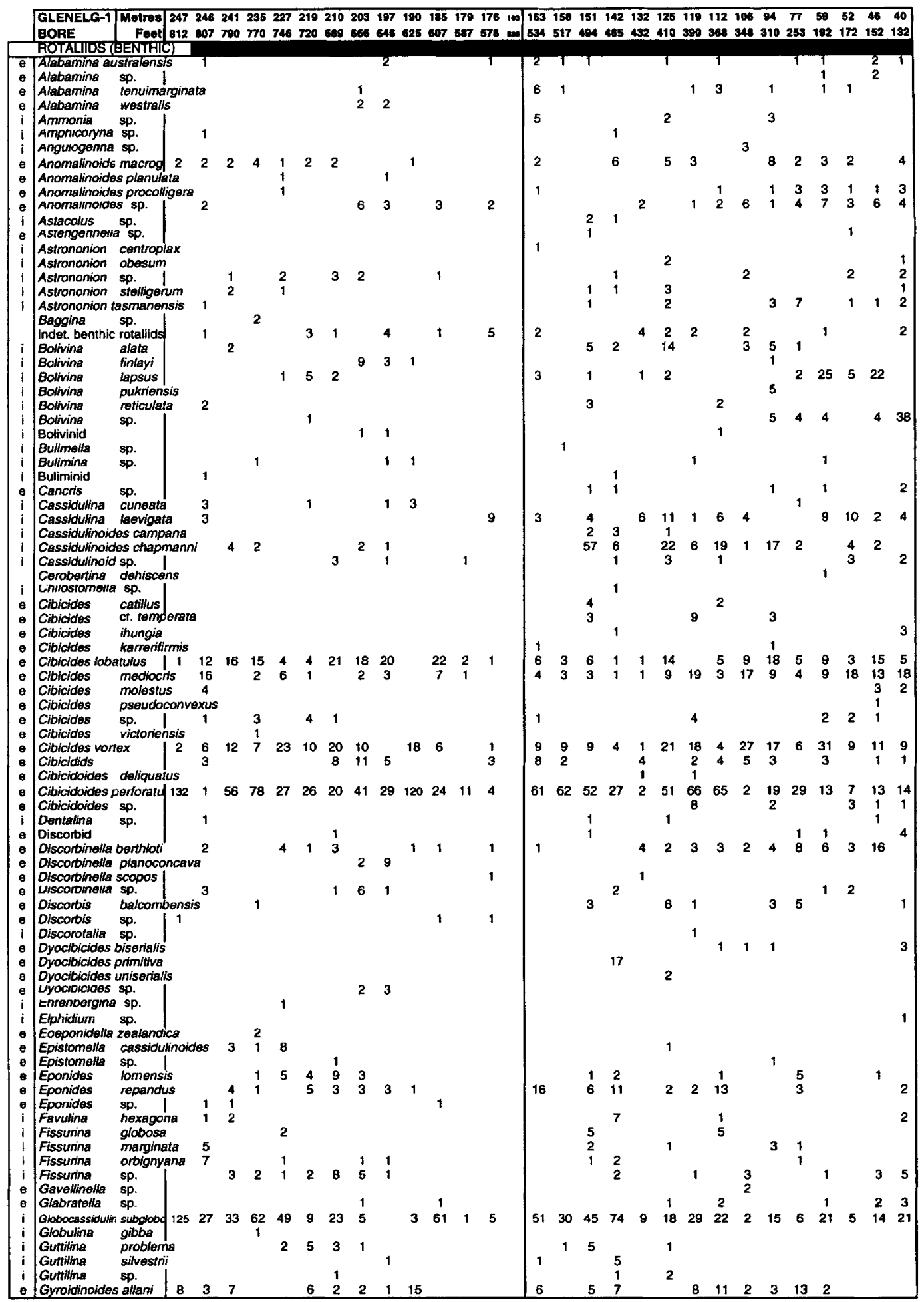

Table A1. Benthonic rotaliid Foraminfera in the Glenelg-1 bore. Note: Anomalinoides macrog = Anomalinoides macroglabra, Cibicidoides perforatu $=$ Cibicidoides perforatus and Globocassidulin subglobo $=$ Globocassidulina subglobosa. 


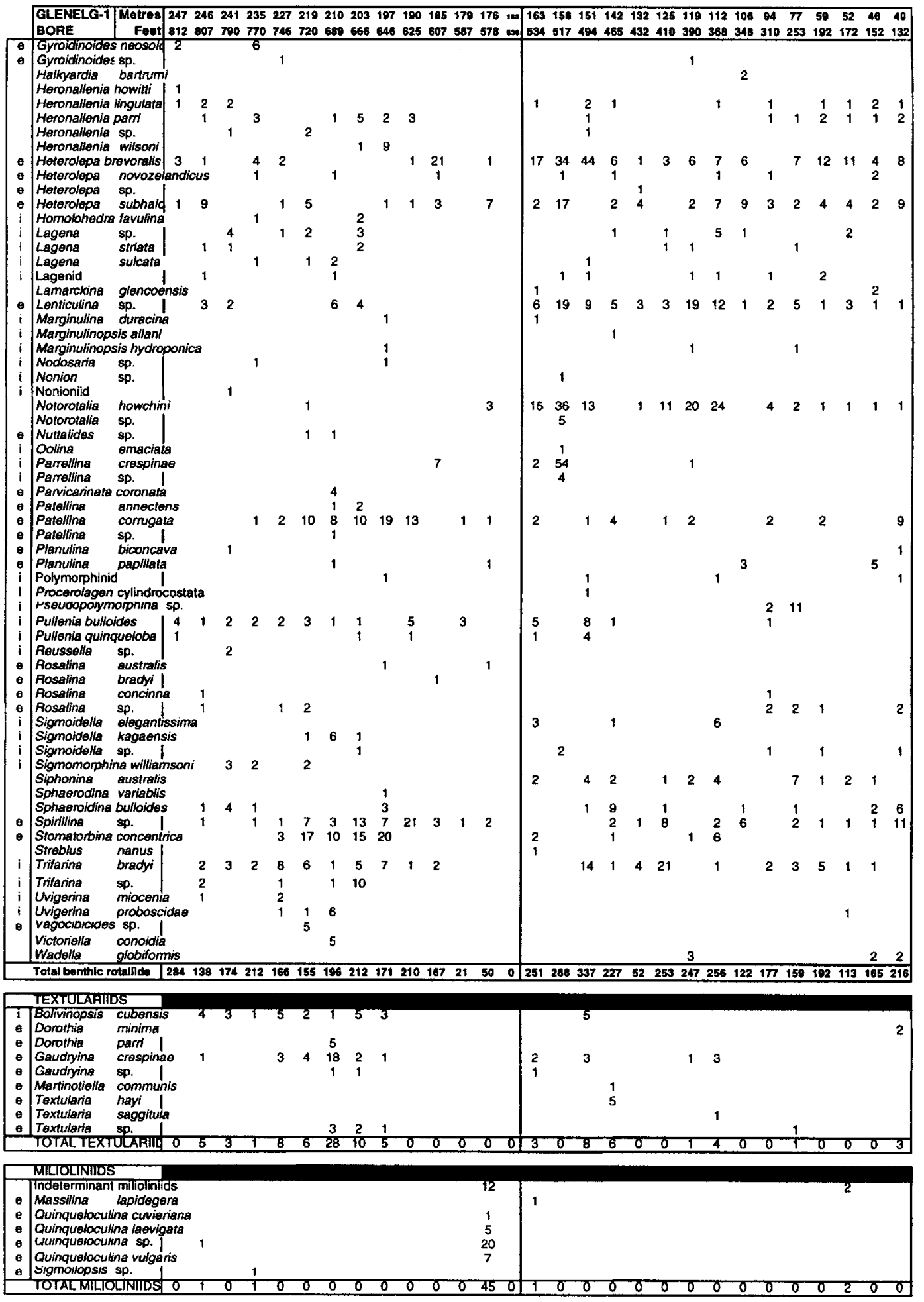

Table A2. List of benthonic rotaliid, textulariid and milioliniid Foraminfera in the Glenelg-1 bore. Note: Gyroidinoides neosol $=$ Gyroidinoides neosodanii and Heterolepa subhaid = Heterolepa subhaidingeri. 


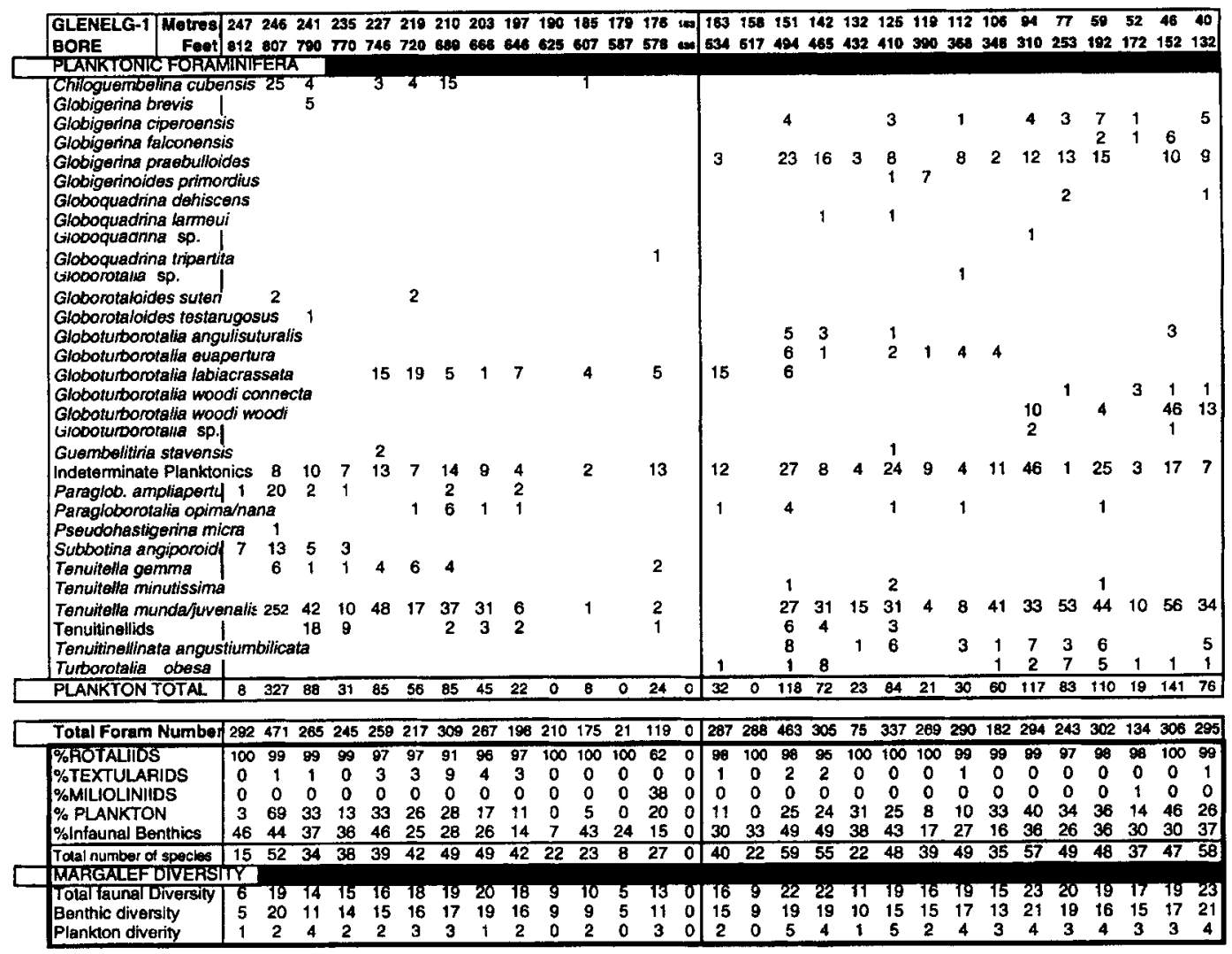

Table A3. List of the planktonic foraminifera, suborder percentages and diversity values for the Glenelg-1 bore. The percentage of infaunal taxa is a minimum value as the benthonic habit of many of the taxa is unknown. Note: Paraglob. ampliapertu= Paragloborotalia ampliapertura and Subbotina angiporoid $=$ Subbotina angiporoides. 


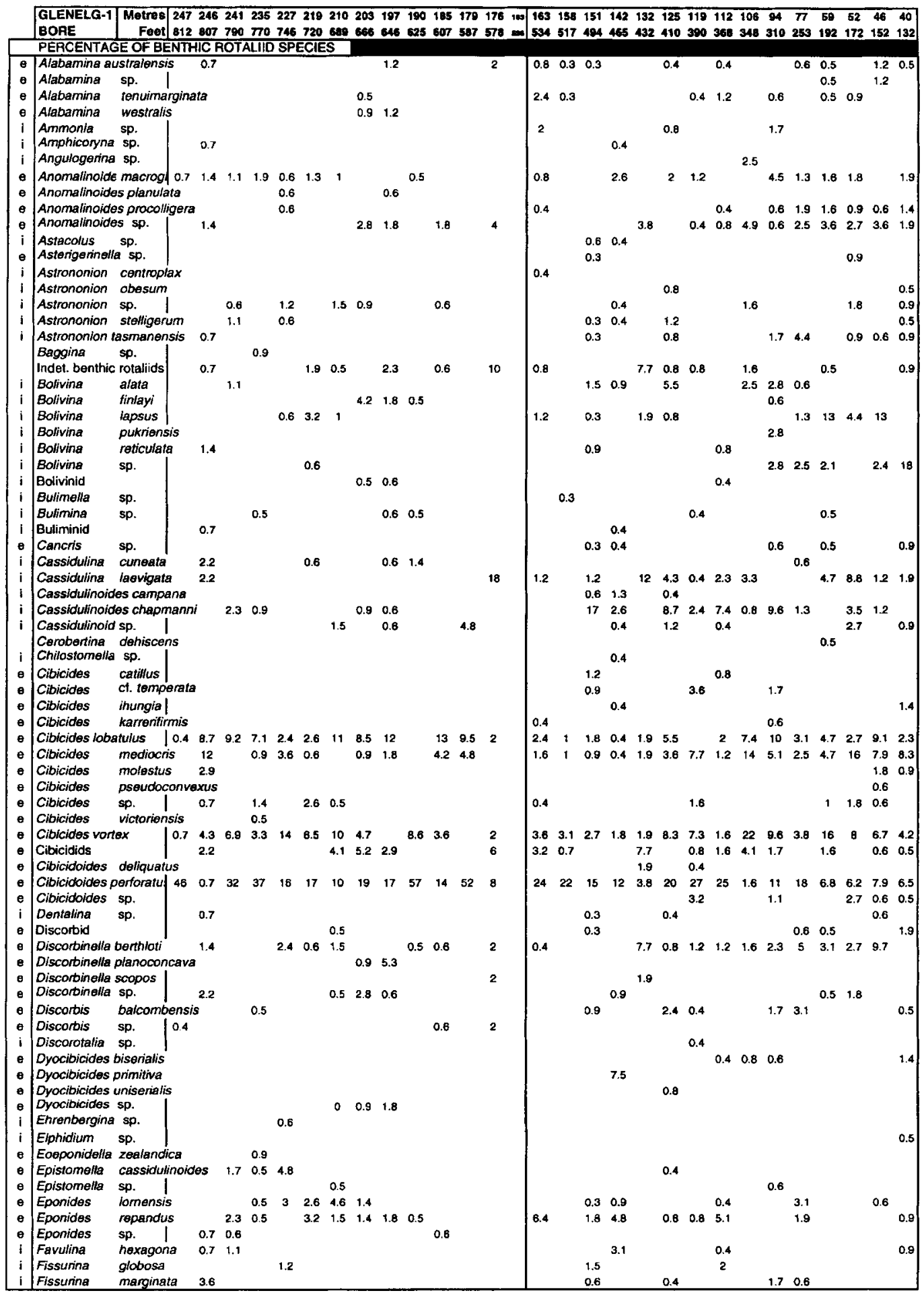

Table B1. Percentage abundance of benthonic rotaliid Foraminfera in the Glenelg-1 bore. Note: Anomalinoides macrog $=$ Anomalinoides macroglabra and Cibicidoides perforatu $=$ Cibicidoides perforatus . 


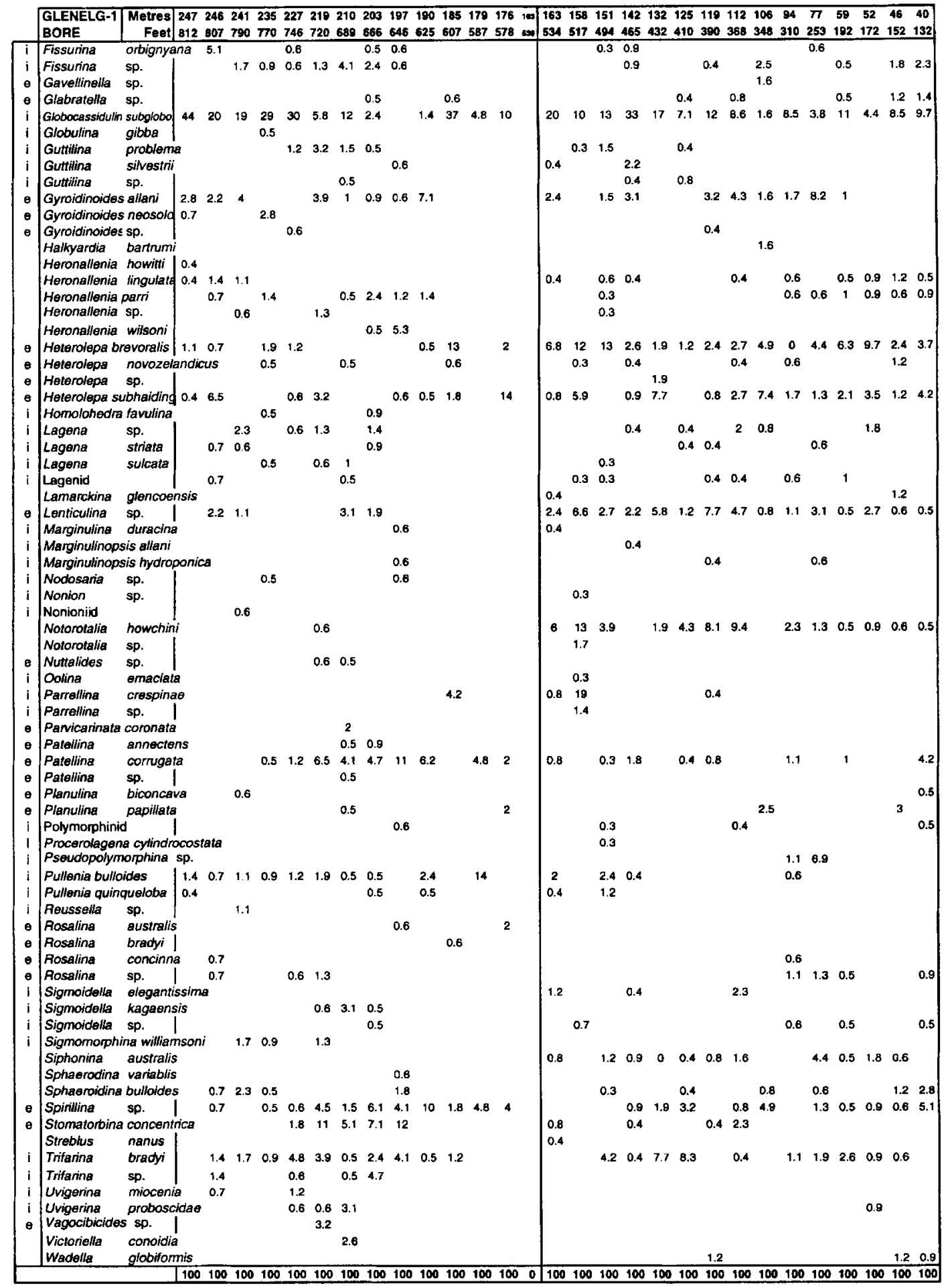

Table B2. Percentage abundance of benthonic rotaliid Foraminfera in the Glenelg-1 bore. Note: Globocassidulin subglobo $=$ Globocassidulina subglobosa, Gyroidinoides neosol $=$ Gyroidinoides neosodanii and Heterolepa subhaiding $=$ Heterolepa subhaidingeri. 




Table B3. Percentage abundance of planktonic foraminifera in the Glenelg-1 bore. Note: Paraglob. ampl= Paragloborotalia ampliapertura and Subbotina angiporoide $=$ Subbotina angiporoides. 


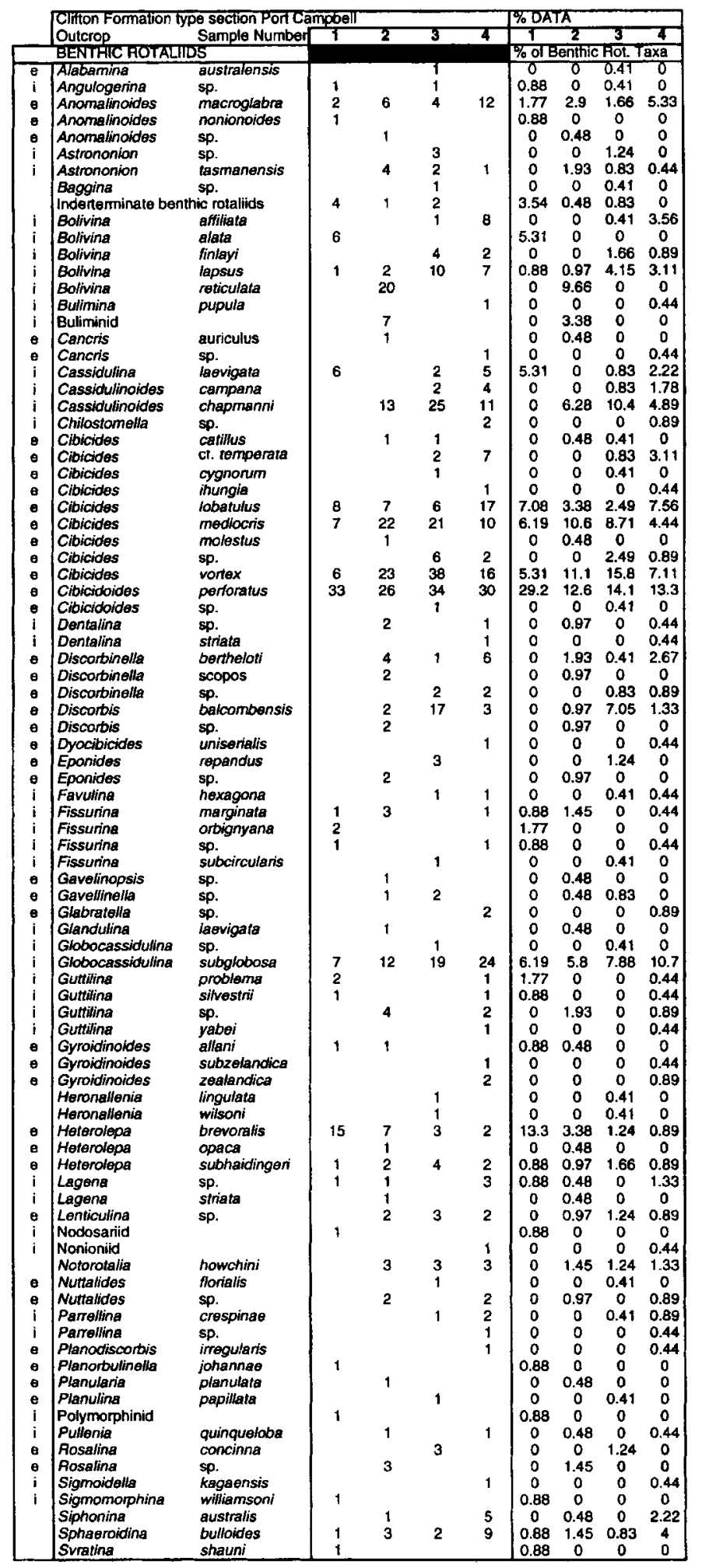

Table C1. List of benthonic rotaliid foraminifera and their percentage abundance in the Clifton Formation type section. 
S. J. Gallagher et al.

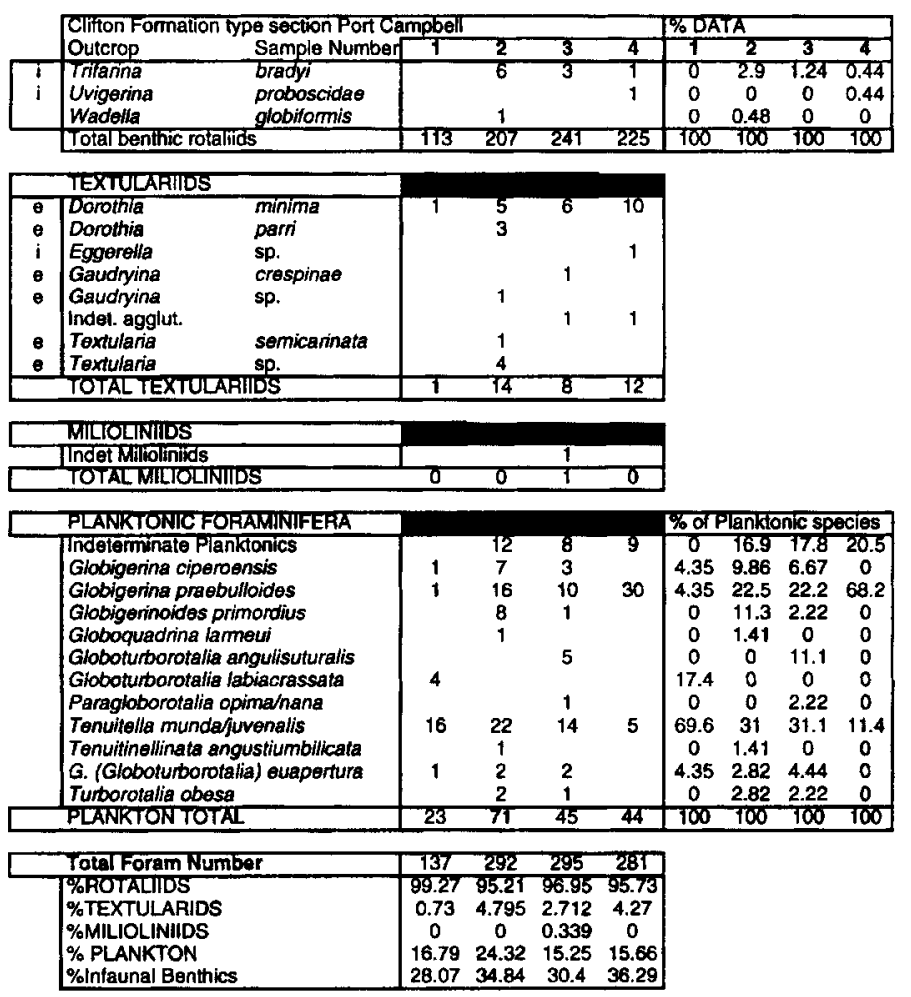

Table C2. List of planktonic and benthonic rotaliid, milioliniid and textulariid foraminifera in the Clifton Formation type section. The percentages of planktonic, benthonic rotaliid, infaunal and foraminiferal suborders are listed. 